\title{
A SUMMARY OF PESTICIDES IN GROUND-WATER DATA COLLECTED BY GOVERNMENT AGENCIES IN INDIANA, DECEMBER 1985 TO APRIL 1991
}

By MARTIN R. RISCH

U.S. GEOLOGICAL SURVEY

Open-File Report 93-133

Prepared in cooperation with the INDIANA DEPARTMENT OF ENVIRONMENTAL MANAGEMENT

Indianapolis, Indiana 


\section{U.S. DEPARTMENT OF THE INTERIOR \\ BRUCE BABBITT, Secretary}

\section{U.S. GEOLOGICAL SURVEY}

Robert M. Hirsch, Acting Director

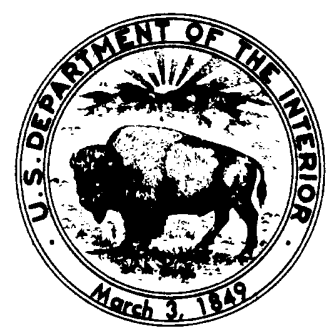

Any use of trade, product, or firm names in this publication is for descriptive purposes

only, and does not imply endorsement of products by the U.S. Government.

For additional information, write to:

District Chief

U.S. Geological Survey

Water Resources Division

5957 Lakeside Boulevard

Indianapolis, IN 46278-1996
Copies of this report can be purchased from:

U.S. Geological Survey

Earth Science Information Center

Open-File Reports Section

Box 25286, MS 517

Denver Federal Center

Denver, CO 80225 


\section{CONTENTS}

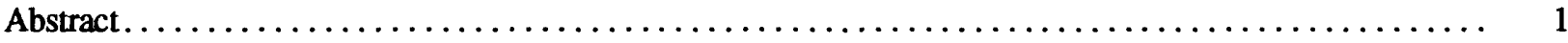

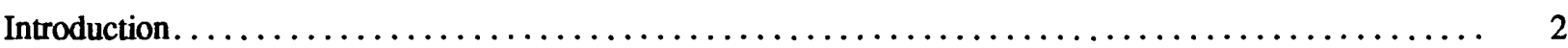

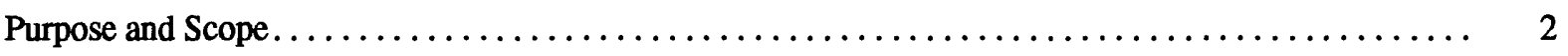

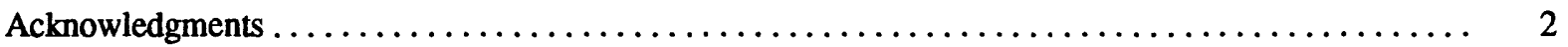

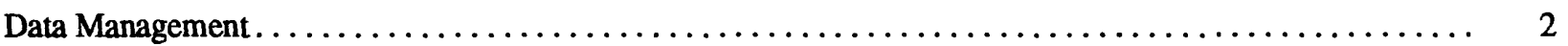

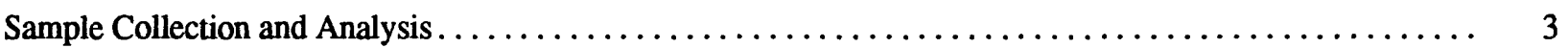

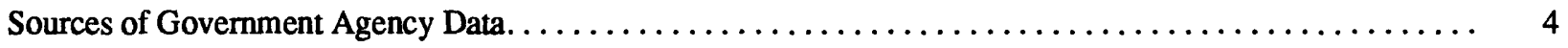

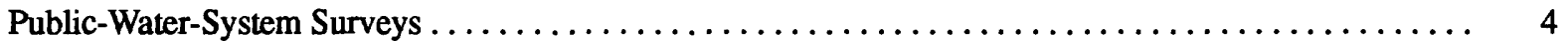

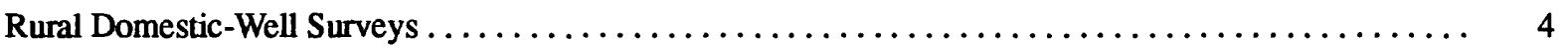

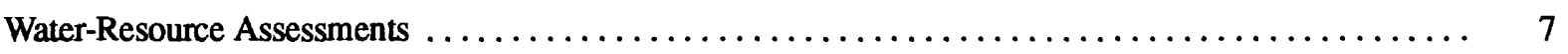

National Survey of Pesticides in Drinking-Water Wells $\ldots \ldots \ldots \ldots \ldots \ldots \ldots \ldots \ldots \ldots \ldots \ldots \ldots$

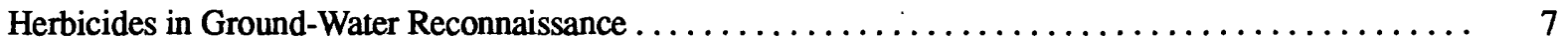

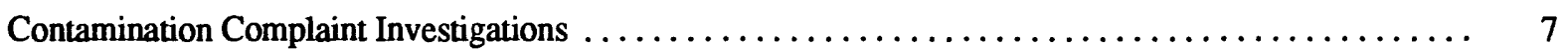

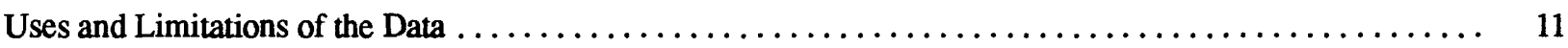

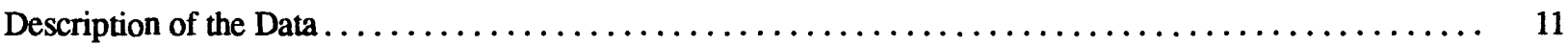

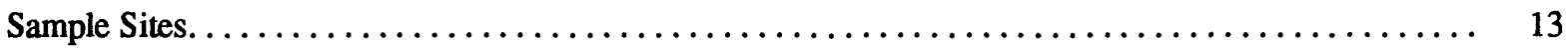

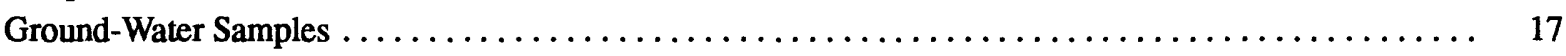

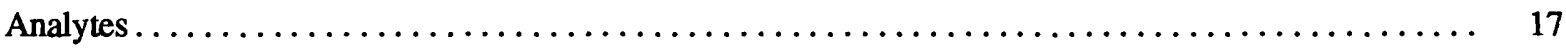

Pesticide Detections. . . . . . . . . . . . . . . . 20

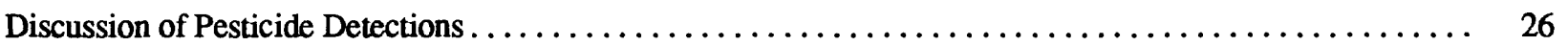

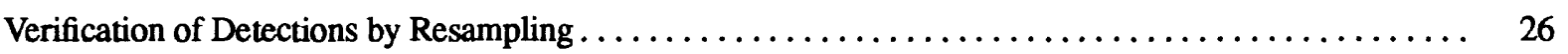

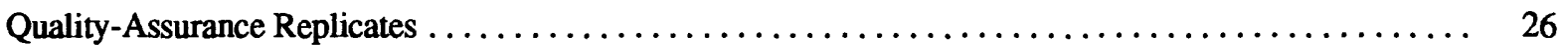

Use of Detected Pesticides. . . . . . . . . . . . . . . . . . . . . . .

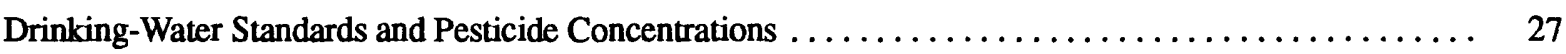

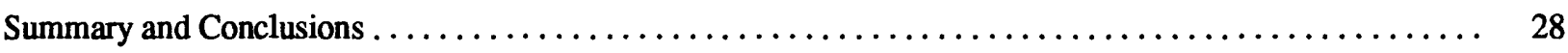

References Cited ..................................................... 30

\section{ILLUSTRATIONS}

\section{1-7 Maps showing:}

1. Location of rural domestic-well-survey-study areas investigated by Indiana Department of

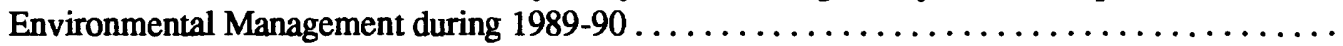

2. Boundaries of water-resource assessment study areas surveyed by Indiana Department of Natural Resources in 1986, 1988, and 1989, including location of wells sampled for

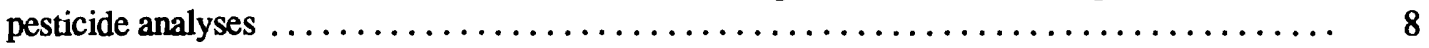

3. Location of wells in Indiana sampled as part of U.S. Environmental Protection Agency national survey of pesticides in drinking-water wells, 1989-90 .

4. Location of wells in Indiana sampled by the U.S. Geological Survey in a 1989 preliminary reconnaissance and a 1991 regional reconnaissance for selected herbicides and nitrate in ground water of the mid-continental United States. 


\section{CONTENTS}

5. Location of wells sampled during ground-water contamination complaint investigations by Indiana Department of Environmental Management during 1985-89 ............ 12

6. Distribution of sites sampled for pesticides during $1985-91 \ldots \ldots \ldots \ldots \ldots \ldots \ldots \ldots \ldots$

7. Location of sample sites with pesticide(s)/metabolite(s) detected during $1985-91 \ldots \ldots \ldots \ldots \quad 24$

\section{TABLES}

1. Data sets used in statewide summary, with number of sites, samples, and analytes . . . . . . . . 5

2. Indiana counties, with number and type of sample sites $\ldots \ldots \ldots \ldots \ldots \ldots \ldots \ldots \ldots \ldots \ldots \ldots \ldots$

3. Number of samples and detections in the data base, by year and by season $\ldots \ldots \ldots \ldots \ldots \ldots \ldots \ldots$

4. Pesticides and metabolites in the data base, with number of samples, pesticide use, regulatory

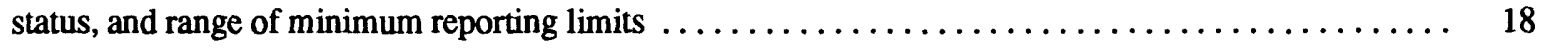

5. Indiana counties, sites, and samples with pesticide detections $\ldots \ldots \ldots \ldots \ldots \ldots \ldots \ldots \ldots \ldots 21$

6. Pesticides and metabolites detected in Indiana ground water, ranked by number of detections, with number of samples, percent detections, and concentration range, mean, and median.......... 25

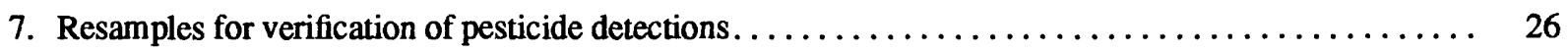

8. Corn and soybean pesticides used in Indiana in 1990, by total pounds applied $\ldots \ldots \ldots \ldots \ldots \ldots \ldots 27$

9. Pesticides and metabolites detected in Indiana ground water, with drinking-water standard, number, and range of concentrations exceeding the standard 


\section{CONVERSION FACTORS AND ABBREVIATED WATER-QUALITY UNITS}

\begin{tabular}{rcll}
\hline Multiply & By & To obtain \\
\hline & & & \\
foot (ft) & 0.3048 & meter \\
acre & 4,047 & meter \\
pound & 0.4536 & kilogram \\
\hline
\end{tabular}

Abbrevlated water-quailty units used in this report: Chemical concentrations are given in metric units. Chemical concentration is given in micrograms per liter $(\mu \mathrm{g} / \mathrm{L})$. Micrograms per liter is a unit expressing the concentration of chemical constituents in solution as weight (micrograms) of solute per unit volume (liter) of water. One thousand micrograms per liter is equivalent to one milligram per liter. 


\title{
A SUMMARY OF PESTICIDES IN GROUND-WATER DATA COLLECTED BY GOVERNMENT AGENCIES IN INDIANA FROM DECEMBER 1985 TO APRIL 1991
}

\author{
By Martin R. Risch
}

\begin{abstract}
The U.S. Geological Survey, in cooperation with the Indiana Department of Environmental Management, computerized the available government agency data on the occurrence of pesticides and pesticide metabolites in Indiana ground water. Results of analy ses of 725 samples were summarized for the period December 1985 through April 1991. The data had been collected during 6 statewide surveys and 15 localized studies by the Indiana Department of Environmental Management, the Indiana Department of Natural Resources, the U.S. Environmental Protection Agency, and the U.S. Geological Survey. Ground-water samples were collected from 521 sites in 81 of 92 Indiana counties, including 179 public-supply wells, 304 domestic-supply wells, 36 observation wells, and 2 springs; 41 percent of all sites were sampled more than once. Thirty wells were sampled in response to alleged groundwater contamination with pesticides.
\end{abstract}

Of 87 pesticides and 10 metabolites analyzed, 18 pesticides and 5 metabolites were detected in 51 samples of ground water from 22 domestic wells, 8 community-system wells, 5 observation wells, 4 non-community-system wells, and 2 springs. Detections associated with complaints of ground-water contamination from pesticide storage, handling, or application occurred at five domestic wells. Three-fourths of all the pesticide detections were in water from wells completed in unconsolidated materials to a depth of less than 100 feet, but well depths ranged from 12 to 260 feet.

The highest frequency of occurrence was observed for the most commonly used herbicides-alachlor, atrazine and two atrazine metabolites (de-ethylatrazine and de-isopropylatrazine); dicamba; 2,4-D; and metolachlor. Also reported in Indiana ground water were eight insecticides whose registration had been cancelled by the U.S. Environmental Protection Agency prior to their detection in Indiana-EDB, DBCP, aldrin, endrin, dieldrin, lindane, heptachlor, and DDT.

More than 1 pesticide was present in 16 of the 51 samples that had detections, for a total of 90 individual pesticide detections. Concentrations of the detected pesticides ranged from 0.04 to 49 micrograms per liter, and two-thirds of the detected concentrations were less than 1 microgram per liter. In about 29 percent of all detections, the concentration of 9 pesticides-alachlor, aldrin, atrazine, dieldrin, EDB, heptachlor, heptachlor epoxide, simazine, and terbufos-exceeded either the U.S. Environmental Protection Agency's Maximum Contaminant Level or adult lifetime Health Advisory. 


\section{INTRODUCTION}

Pesticides to control unwanted and harmful weeds and insects are an important tool of agriculture and landscape maintenance.

Widespread use of these chemicals has caused public concern about the potential for groundwater contamination. In the United States, there is evidence that ground water has been contaminated with pesticides. In 1988, Williams and others of the U.S. Environmental Protection Agency (USEPA) reported 46 pesticides had been found in the ground water of 26 states. A similar nationwide summary of data by Parsons and Witt (1988) of Oregon State University reported 67 pesticides were found in ground water from 33 states. From the national survey of pesticides in drinking-water wells, USEPA (1990a) inferred that 7.1 percent of the 94,600 community-water-system wells and 3.2 percent of the rural domestic wells in the United States could contain detectable levels of pesticide or nitrate.

A potential exists in Indiana for ground water to become contaminated with pesticides. Nearly 60 percent of Indiana's population depends on ground water as a source of drinking water, and a majority of the water-supply wells are in rural locations. Over half of the public-water-supply wells are outside city limits, and almost 90 percent of rural, self-supplied water comes from wells. About 70 percent of the land use in Indiana is agricultural, including 13 million acres of cropland with 10 million acres planted in corn and soybeans. The U.S. Department of Agriculture (USDA) Indiana Agricultural Statistics Service (1991) reported a total of 28 million pounds of com and soybean pesticides were applied in Indiana in 1990. Of that total, 26.6 million pounds were herbicides applied to 96 percent of the corn and soybean crops that year.

Starting in 1985, ground-water quality monitoring projects were conducted in Indiana by two State and two Federal government agencies to assess the nature and extent of ground-water contamination by pesticides in Indiana. The projects varied in design and purpose, and included 6 statewide surveys and 15 localized studies. The findings were stored in about 25 sets of paper files at several locations, and there had been no data base previously assembled to document the extent of the contamination. During 1990-91, the U.S. Geological Survey (USGS), in cooperation with the Indiana Department of Environmental Management (IDEM), combined the available information from these different ground-water monitoring projects into a computerized data base with statewide coverage.

\section{Purpose and Scope}

This report describes the methods used to compile and computerize sample site information and pesticide analytical data for Indiana ground water from files at IDEM, USGS, USEPA, and the Indiana Department of Natural Resources (IDNR). This report also summarizes the data for the time period December 1985 through April 1991.

\section{Acknowledgments}

The author acknowledges the cooperation of Gregg Lemasters of the Indiana Department of Environmental Management Ground Water Section, who was instrumental in providing much of the information that went into the data base. Appreciation is also extended to two project assistants, Kevin Selwa and Jennifer Whikehart.

\section{DATA MANAGEMENT}

The USGS assembled a project file for each sample location. The file typically included paper copies of laboratory analysis reports, field notes, memoranda, and correspondence, plus ancillary information such as well construction records and site maps. Locations of the wells and springs sampled were plotted on 1:24,000 topographic 
maps. The latitude and longitude of each location were obtained by use of a digitizing table and computer program. The latitude and longitude of each site, the source agency for the data, and a twodigit sequence number were used to construct a unique identification number (ID), and each site was compared with nearby sites in the data base to guard against duplication.

The USGS National Water Information System (NWIS) software was used to store sample site characteristics such as location, name, well depth, water use, well construction date, aquifer type, geologic unit code, and sources of information. Well data was obtained from driller's records and geologist's field notes.

NWIS also was used to store the water-quality data. Each sample was identified by ID plus date and time of sample collection. Each chemical was represented in NWIS by a five-digit numerical code, the same code used in USEPA's waterquality data system. Chemical codes were based on unique combinations of sample matrix, analytical method, and concentration unit. Information entered into the data base for each sample included chemical names and concentrations, sample source, sample method, well purging method, site selection method, collection agency, and analyzing laboratory.

\section{SAMPLE COLLECTION AND ANALYSIS}

Staff from IDEM, USEPA, USGS, and IDNR collected 824 of the 875 ground-water quality samples in the data base. An additional 41 samples were collected by a USEPA contractor, and 10 samples were collected by county health department staff. Samples were collected at a tap before the water had received treatment, such as softening or chlorination. Wells and plumbing were purged of stagnant water by either flushing 15 minutes before samples were collected or fieldmonitoring for stable values of $\mathrm{pH}$, specific conductance, and temperature. Sample containers were solvent-rinsed, oven-dried glass bottles or vials with teflon-septum lids. Samples from drinking-water-supply wells were collected at cold water taps as close to the wellhead as possible. Samples collected by the USGS at monitoring wells were obtained by use of either a peristaltic pump at the wellhead or a submersible, positivedisplacement pump in the well. USGS sampling equipment was cleaned with detergent solution and deionized water rinses to minimize crosscontamination between wells.

Of the 875 samples, 150 were quality-assurance replicates collected at the same time and in the same manner as the 725 ground-water samples. In addition to the 875 samples, 111 trip blanks were analyzed. Trip blanks were vials of contaminantfree water transported and stored with both empty and filled water sample containers. Water used for trip blanks was filtered through activated carbon to remove organic chemical contaminants. Trip blanks were analyzed along with the ground-water samples to detect contaminants accidentally introduced into samples during transport, storage, or in the laboratory. Results for the replicates and blanks were evaluated and included in the data base for reference on quality assurance.

Some sample analysis was performed by the Indiana State Board of Health laboratory and several private laboratories, each certified by USEPA for the Safe Drinking Water Act program. Other analysis was done by IDEMcontracted laboratories providing quality-control, quality-assurance, and analytical methods suitable for Indiana's hazardous waste management program. Laboratory quality-assurance documentation was available for samples analyzed at contract laboratories. Analytical results for which there were documented quality-control or qualityassurance problems were not included in the data base. The 61 samples collected by USGS staff were analyzed at 2 USGS water-quality laboratories. 
Analytical methods included gas chromatography with mass spectrometry, high performance liquid chromatography, gas chromatography with a nitrogen-phosphorous detector, and gas chromatography with an electroncapture detector. Positive detections were confirmed on a different instrument or through a different technique. Nearly all samples were unfiltered and the analytical results were reported as the total, recoverable concentration of a chemical. Thirty samples collected by USGS were processed through a 0.30 -micrometer filter in the field, and the analytical results reported as dissolved chemical concentrations.

\section{SOURCES OF GOVERNMENT AGENCY DATA}

About 25 different data sets were compiled and entered into the data base. Table 1 lists the names of the surveys and study areas for the data sets, along with the general time period for sample collection, number of wells sampled, number of samples, plus the number of pesticides and metabolites analyzed. Brief descriptions of the sources of the data follow.

\section{Publlc-Water-System Surveys}

In the fall of 1987, IDEM and USEPA conducted a water-quality survey of public-watersystem wells in Indiana. Systems included both community and non-community types. Community systems supply 25 or more persons, or at least 15 service connections for 60 or more consecutive days per year. Non-community systems serve these same numbers less than 60 consecutive days per year. For example, community systems include cities, towns, and mobile home parks; non-community systems include schools, churches, restaurants, camps, and motels. Systems in the survey were selected by a stratified, random sample method, and the number of samples per type of system was consistent with the ratio of non-community to community systems in the State (Indiana Department of Environmental Management, 1990). Wells located in urban areas or near facilities used for the storage, handling, or manufacturing of pesticides were not excluded from the survey.

In spring and summer 1988, IDEM sampled public-water-system wells considered to be vulnerable to contamination with pesticides (Indiana Department of Environmental Management, 1990). The criteria used to select vulnerable well fields included (1) rural location; (2) completion in unconsolidated aquifer material; and (3) the absence of significant, subsurface clay above the screened interval of the wells. All of the community-system well fields in the State satisfying these criteria were sampled. All of the spring 1988 sites were community-system wells, and nearly all of these wells were sampled again in summer 1988. About 35 non-communitysystem wells also were sampled in summer 1988 . Wells with detections of pesticides or volatile organic chemicals (VOC's) were resampled within 3 months to verify the continued presence of the chemicals.

\section{Rural Domestic-Well Surveys}

In 1989 and 1990, IDEM made water-quality surveys in six study areas which contained rural domestic wells in vulnerable geologic settings and with agricultural land use (Indiana Department of Environmental Management, 1990). Five of the six study areas included sand and gravel, watertable aquifers; the sixth was karst limestone. Wells were chosen to avoid sites where agricultural chemicals were stored or handled. Figure 1 shows the locations of the six rural-well study areas.

In two 1989 study areas (Topeka in LaGrange and Noble Counties, and North Newton in Newton County), wells were sampled approximately three times during the growing season, including before and after planting, and at harvest. Both study areas had irrigated croplands planted mainly in com and soybeans. The Lost River study area (located in 


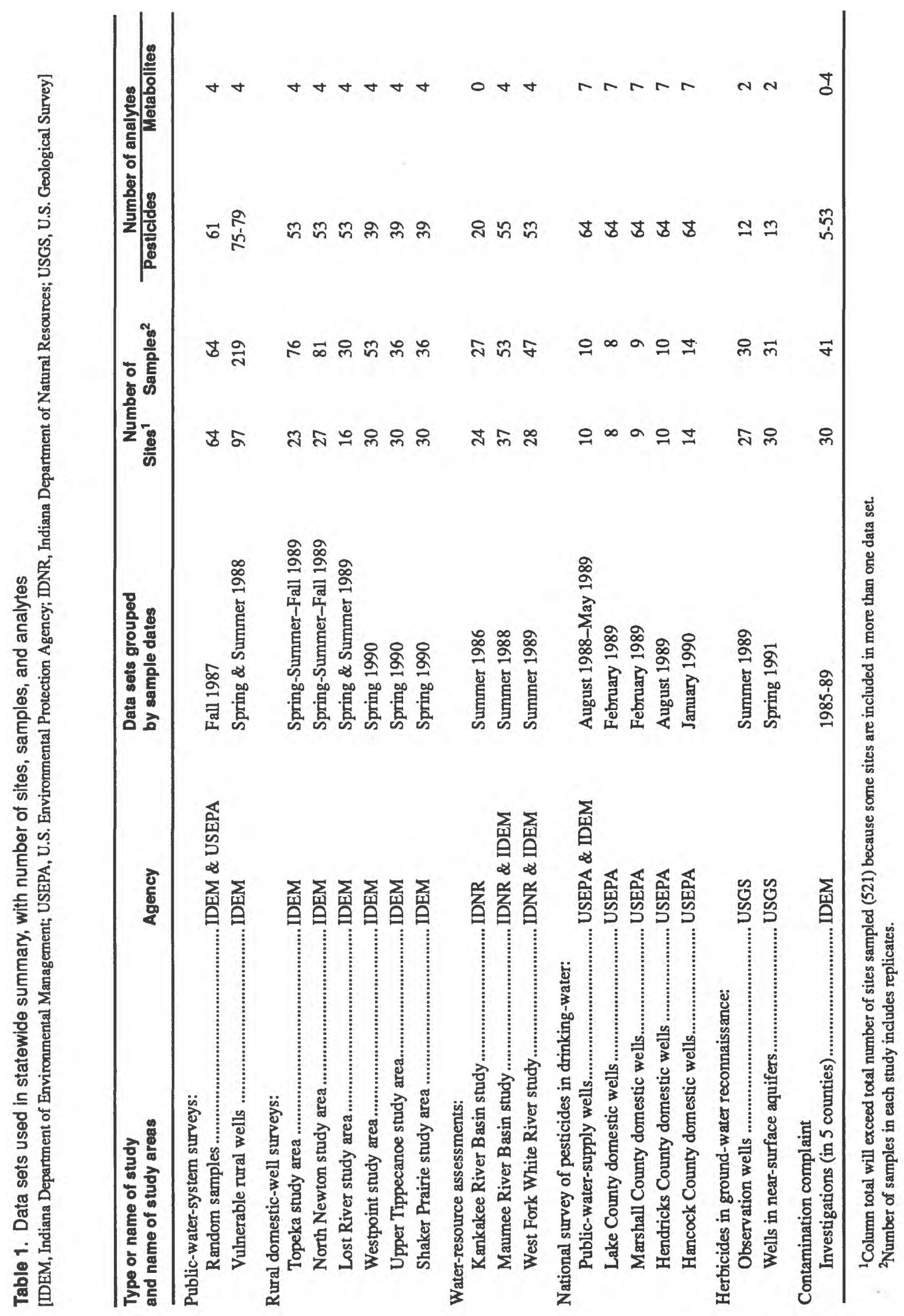




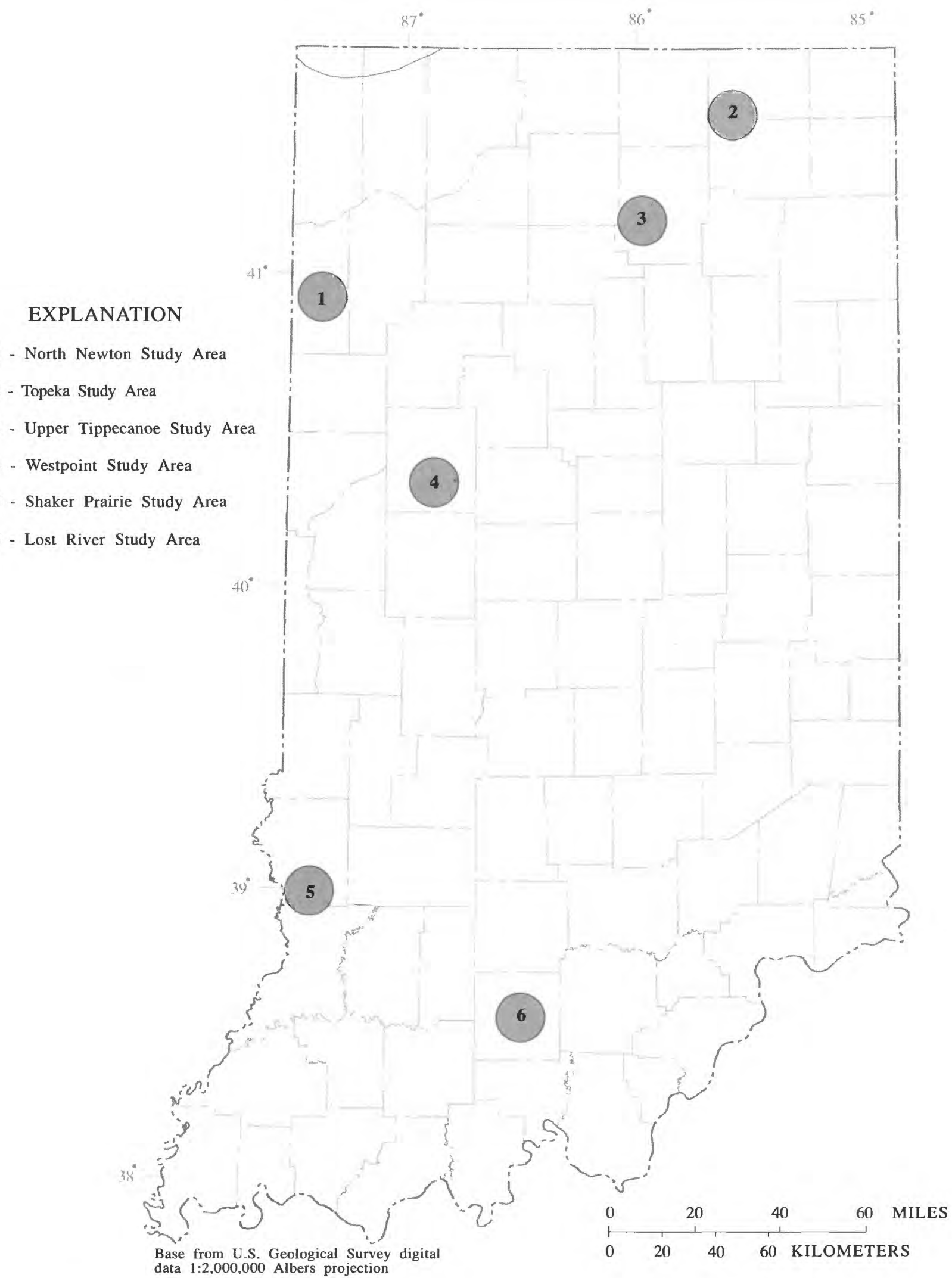

Figure 1. Location of rural-domestic-well-survey study areas investigated by Indiana Department of Environmental Management during 1989-1990. 
south-central Indiana and characterized by sinkholes, underground streams, and springs) also was sampled in 1989. Most agricultural land in the Lost River area was in corn and pasture. Waterquality samples were collected in the spring and summer at five public-water-supply wells, two springs, and nine domestic wells.

In 1990, IDEM continued the rural-well surveys in three other locations-Westpoint in Tippecanoe County, Shaker Prairie in Knox and Sullivan Counties, and Upper Tippecanoe in Kosciusko County. Thirty wells in each study area were sampled in late spring. Corn and soybeans were major crops in the Westpoint and Upper Tippecanoe study areas, while the Shaker Prairie study area included many acres of melons and market crops.

\section{Water-Resource Assessments}

IDNR conducted water-resource assessment studies in the Kankakee River Basin in 1986, the Maumee River Basin in 1988, and part of the West Fork White River Basin in 1989 (fig. 2). IDNR specifically chose wells thought to be unaffected by contaminant sources. This choice was made so that water sample analyses could be termed representative of general ground-water quality near the wells. IDEM selected a subset of the IDNR wells to have samples collected for pesticide analysis (Indiana Department of Environmental Management, 1990). Between 24 and 37 wells were sampled in each basin. Sites with positive detections of pesticides or VOC's were resampled within 3 months to determine if the chemicals were still present.

\section{National Survey of Pesticides in Drinking-Water Wells}

USEPA conducted a nationwide survey of drinking-water quality in community-water-system wells and rural domestic wells during 1988-90 (U.S. Environmental Protection Agency, 1990a). This survey included 51 sample locations in Indiana (fig. 3). USEPA used a stratified random sample design, based on 12 combinations of generalized vulnerability of ground water to contamination and on pesticides use. The sample design determined the counties included in the survey.
Community-water systems were randomly selected from the eligible counties within these strata.

Rural domestic wells were chosen from subregions in those counties, based on further stratification by cropping intensity and ground-water vulnerability. In Indiana, 10 community-water systems in 10 counties throughout the State were sampled, along with a total of 41 rural domestic wells in Lake, Hendricks, Hancock, and Marshall Counties.

\section{Herbicides in Ground-Water Reconnaissance}

The USGS performed a preliminary reconnaissance of ground-water quality in Indiana in 1989. Thirty water samples were collected from 27 shallow observation wells in rural locations statewide. These samples were analyzed for 12 herbicides and nitrate.

In 1991, the USGS included Indiana in a regional reconnaissance for selected herbicides and nitrate in ground water of the mid-continental United States. The purpose of the study was to determine the spatial and seasonal distribution of nonpoint-source herbicide and nitrate contamination in near-surface aquifers of the corn and soybean-producing region of the midwest (Kolpin and Burkhart, 1991). Twenty wells in near-surface unconsolidated aquifers and 10 wells in nearsurface bedrock aquifers were sampled (fig. 4). Near-surface aquifers were defined as having the top of the aquifer within 50 feet of the land surface. The 1991 survey included a stratified random sample of observation wells, public-water-supply wells, and rural domestic wells. Three of the observation wells sampled in 1991 also had been sampled in 1989. The analytes, sampling protocols, and laboratories were different between the 1989 and 1991 USGS samples.

\section{Contamination Complaint Investigations}

During 1985-89, IDEM investigated six complaints in five counties involving alleged ground-water contamination with pesticides (written commun., Indiana Department of Environmental Management, Ground Water Section; 1986, 1988, 1989). The complaints were about sites for agricultural chemical storage and handling or pesticide application. Water samples were 


\section{EXPLANATION}

WATER-RESOURCE

ASSESSMENT STUDY AREA

Kankakee River Basin (1986)

Maumee River Basin (1988)

West Fork White River Basin (1989)

LOCATION OF WELL SAMPLED

FOR PESTICIDE ANALYSES

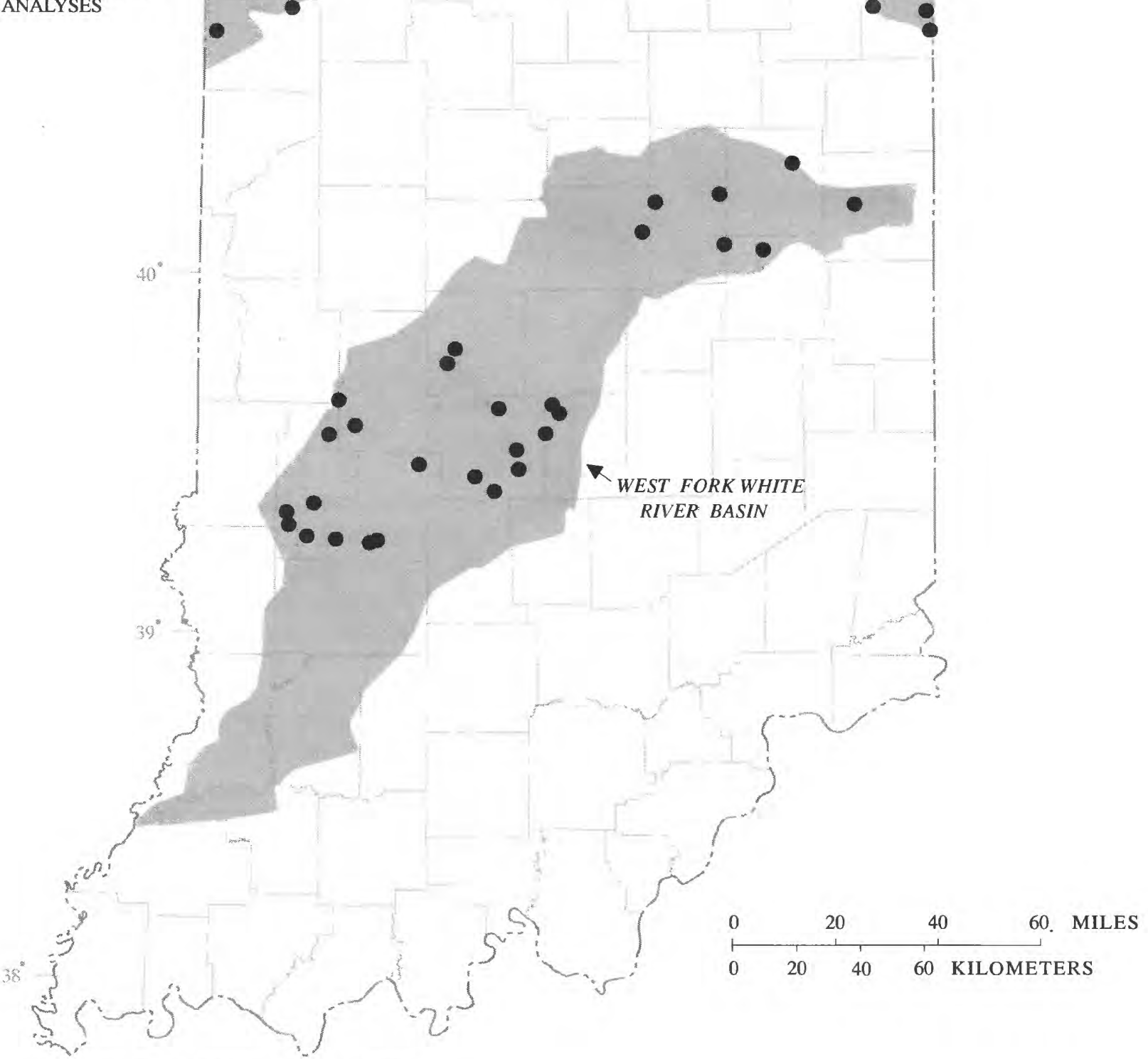

Base from U.S. Geological Survey digital data $1: 2,000,000$ Albers Projection

Figure 2. Boundaries of water resource assessment study areas surveyed by Indiana Department of Natural Resources in 1986, 1988, and 1989, including location of wells sampled for pesticide analyses.

8 A Summary of Pesticides in Ground-Water Data 
EXPLANATION

P Public-water-system well

- Domestic water-supply well

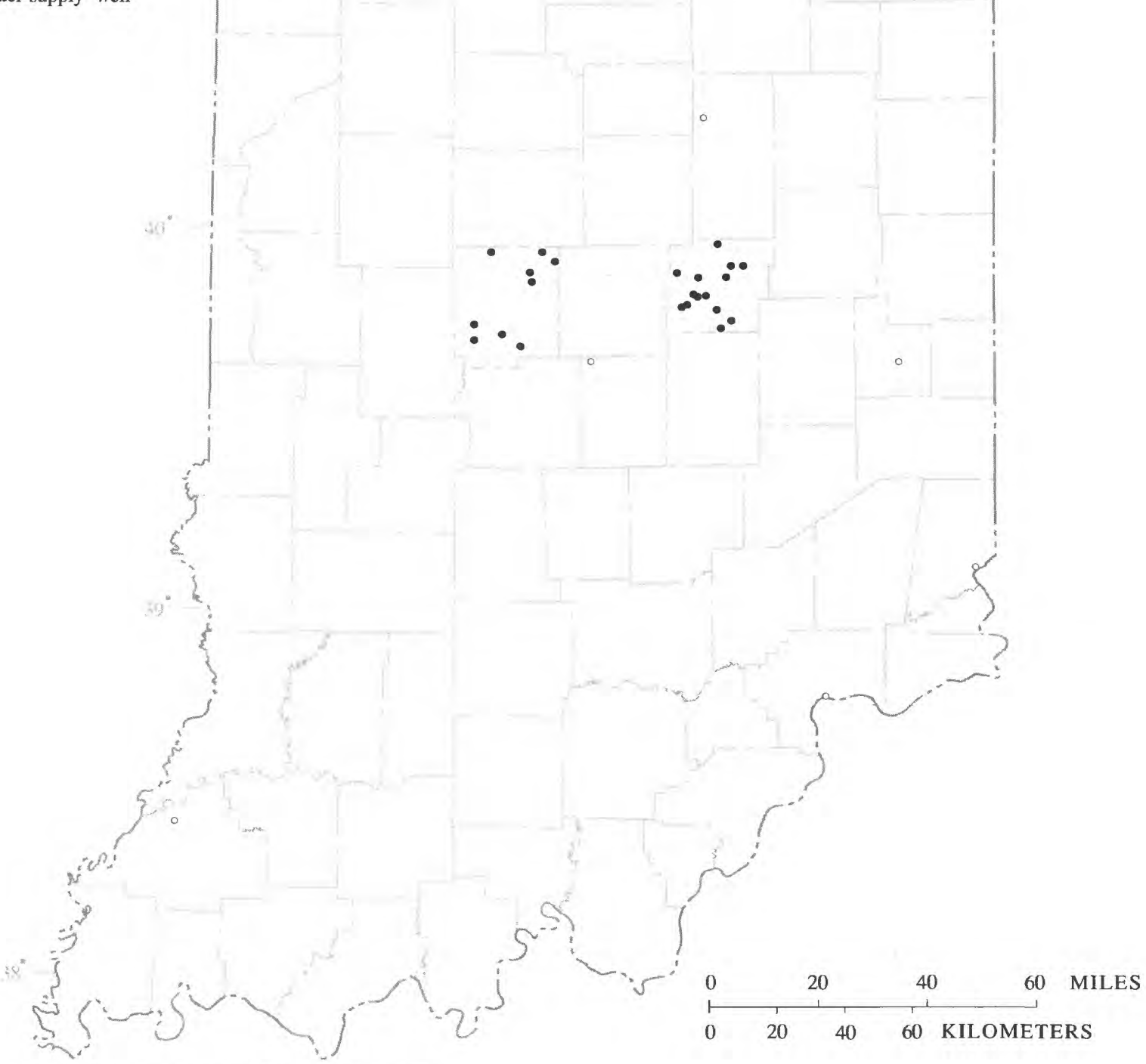

Base from U.S. Geological Survey digital data 1:2,000,000 Albers Projection

Figure 3. Location of wells in Indiana sampled as part of U.S. Environmental Protection Agency national survey of pesticides in drinking-water wells, 1989-90. 
EXPLANATION

A SHALLOW OBSERVATION WELLS

SHALLOW OBSERVATION WELLS (1989 \& 1991)

- WELL IN NEAR-SURFACE UNCONSOLIDATED AQUIFER (1991)

WELL IN NEAR-SURFACE BEDROCK AQUIFER (1991)

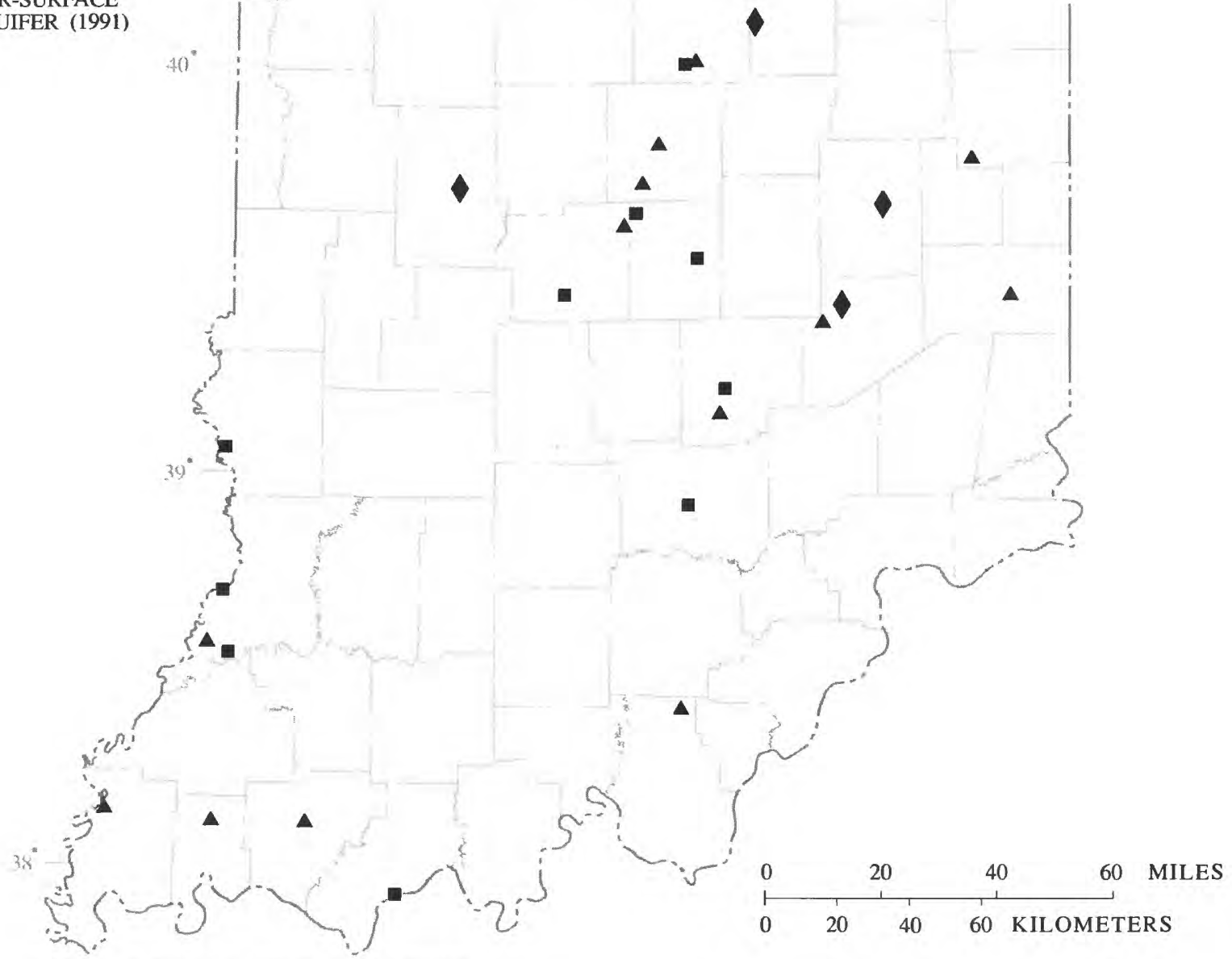

Base from U.S. Geological Survey digital data $1: 2,000,000$ Albers Projection

Figure 4. Location of wells in Indiana sampled by U.S. Geological Survey in a 1989 preliminary reconnaissance and a 1991 regional reconnaissance for selected herbicides and nitrate in ground water of the mid-continental United States. 
collected from 30 domestic wells (fig. 5) as part of these investigations. These 30 wells were the only ones in the data base that had been sampled because of a suspected source of pesticide contamination. (Of these 30 wells, one well each in 5 of the 6 complaint investigations was found to contain detectable concentrations of pesticides.) The specific pesticides analyzed among the 6 complaint investigations varied considerably; the number of analytes varied between 5 and 53 .

\section{USES AND LIMITATIONS OF THE DATA}

This summary of pesticide data in Indiana ground water can be beneficial in several ways. Used alone, this data compilation can help researchers select locations and pesticides in Indiana which merit more detailed scientific investigation. Findings from analysis of the data base could be used by regulatory agencies to identify pesticides and parts of the State that could be priorities for ground-water protection. In a geographic information system, the data on pesticide detections can be analyzed relative to spatial data such as soil characteristics, aquifer types, and land use-factors that may influence the occurrence of pesticides in ground water. Statistical inferences based on such analysis could be useful in the design of a statewide ground-water monitoring network for pesticides.

Some limitations in the use of the data are described in the following discussion. First, even though the data base contains information on 87 pesticides and 10 metabolites, not all of the pesticides that have been used in the State were included. For example, the USDA Indiana Agricultural Statistics Service (1991) listed 44 pesticides that were used on the 1990 Indiana corn and soybean crop, but analyses were available for only 26 of the 44 pesticides listed. Some of the more widely-used pesticides without analyses included chlorimuron-ethyl, bentazon, linuron, acifluorfen, and imazaquin. Water-quality data also were unavailable for some pesticides used in lawn care, right-of-way maintenance, forestry, structural pest control, and specialty crop production. Physical, chemical, and biological processes degrade most pesticides into different compounds (metabolites); however, the data base contained analyses for only 10 of the many known metabolites.

Secondly, comparisons of detection frequency among analytes were complicated by three factors associated with this data compilation: (1) the minimum concentrations reported for analytes varied between data sets, although for most analytes, this variance was less than an order of magnitude difference; (2) the same analytes were not tested in every sample; and (3) the number of samples tested per analyte ranged from 30 to 716 . Therefore, some comparisons of detection frequency could be disproportionate because analytes and minimum reported concentrations were not the same for all samples.

Finally, with this data summary alone it is not possible to make regional or statewide inferences about the occurrence of pesticides in Indiana ground water. No uniform statistical design was used to collect the data compiled for this report; different types of studies were combined. Among the studies, there is variation and bias in the selection of sample sites and in the timing and frequency of sample collection. Variation among studies also can be found in the number of analytes, in the minimum reported concentrations, and in the analytes tested.

\section{DESCRIPTION OF THE DATA}

Following is a description of the data summarized for the period December 1985 through April 1991. The distribution, type, and geologic setting of the wells and springs are reported. Types and temporal distribution of the ground-water samples and the analytes tested in the samples are explained. The numbers, names, and concentrations of pesticide detections are described. 


\section{EXPLANATION}

- Water-supply well

- Cluster of 2-5 water supply wells Cluster of 13 water supply wells

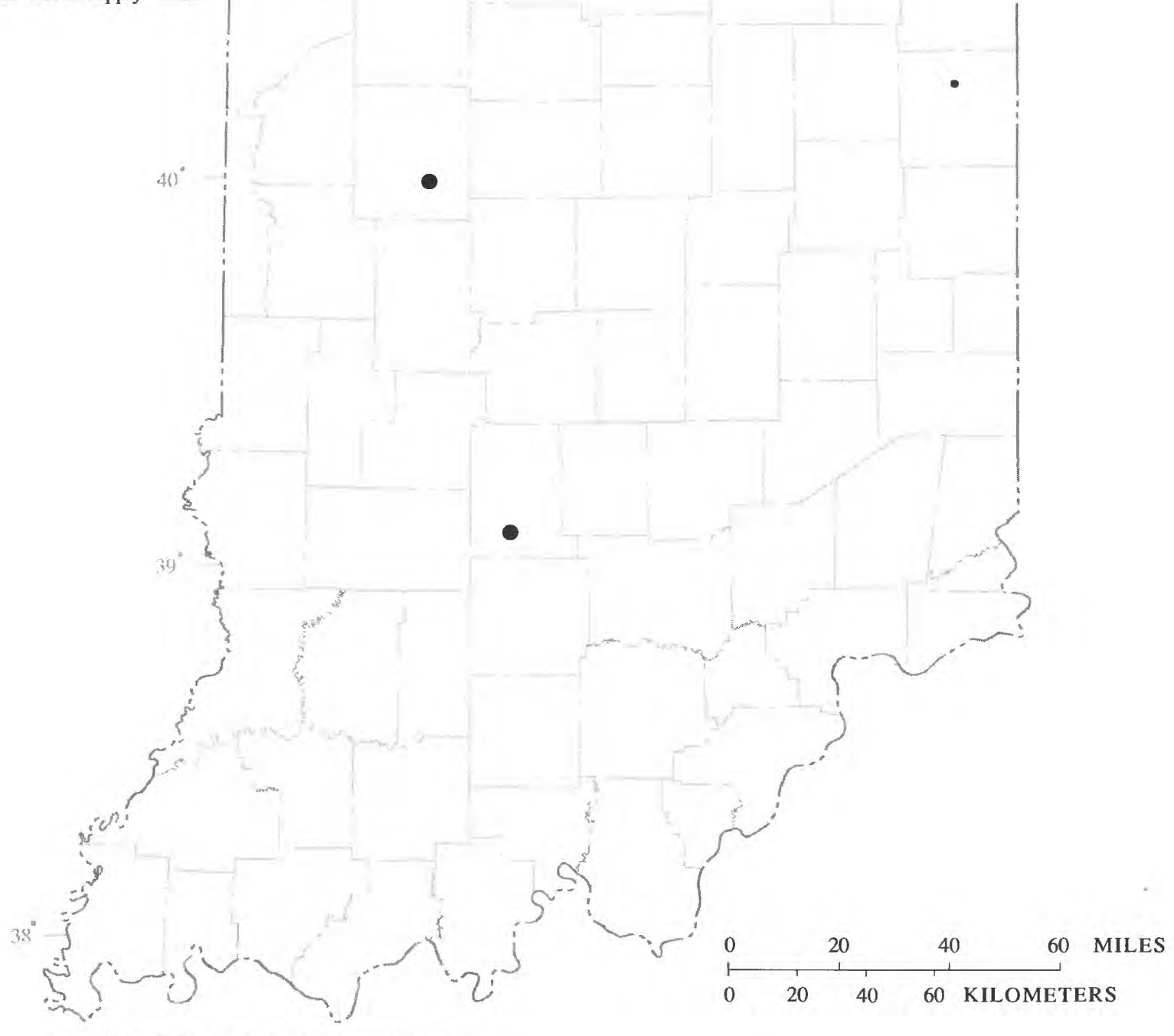

Base from U.S. Geological Survey digital data 1:2,000,000 Albers Projection

Figure 5. Location of wells sampled during ground-water contamination complaint investigations by Indiana Department of Environmental Management 1985-89.

\section{A Summary of pesticides in Ground-Water Data}




\section{Sample Sites}

Water samples analyzed for pesticides were collected from wells in 81 of the 92 counties in Indiana. Table 2 lists the numbers and types of sample sites in each county. Although the median number of sample sites per county was 2 , the number sampled ranged from 0 to 43, with 7 counties having 20 or more wells-Kosciusko (43), Newton (36), Tippecanoe (33), Sullivan (22), Noble (20), Knox (20), and LaGrange (20).
Figure 6 shows the statewide distribution of sample sites per county. Of the 12 types of sample sites in the data base, 304 ( 58 percent) were domestic-supply wells, 179 (34 percent) were public-water-supply wells for 106 community and 73 non-community systems, 36 ( 7 percent) were observation wells, and 2 were natural springs.

When available, information about the depth of the sampled well and the geologic unit in which the well was completed was recorded in the data base.

Table 2. Indiana counties, with number and type of sample sites

[MUN, municipal well; SDV, residential subdivision well; MHP, mobile home park well; SCH, school well; CHR, church well; GOL, golf-course clubhouse well; CMP, camp or campground well; GOV, government facility well; OTH, other restaurant, lodge, or office well; DOM, domestic well; OBS, observation well; SPR, natural spring; TOT, total number of sample sites in county]

\begin{tabular}{|c|c|c|c|c|c|c|c|c|c|c|c|c|}
\hline \multirow[b]{3}{*}{ County } & \multicolumn{8}{|c|}{ Public-Water Supply } & \multirow[b]{3}{*}{ DOM } & \multirow{3}{*}{ OBS } & \multirow[b]{3}{*}{ SPR } & \multirow[b]{3}{*}{ TOT } \\
\hline & \multicolumn{2}{|c|}{$\begin{array}{l}\text { Community- } \\
\text { water system }\end{array}$} & \multicolumn{6}{|c|}{$\begin{array}{l}\text { Non-community- } \\
\text { water system }\end{array}$} & & & & \\
\hline & SDV & MHP & SCH & CHR & GOL & CMP & GOV & OTH & & & & \\
\hline Adams ..................................... & 0 & 0 & $\mathbf{0}$ & 1 & 0 & 0 & 0 & 0 & 9 & 0 & $\mathbf{0}$ & 12 \\
\hline 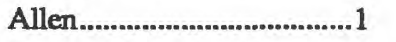 & 0 & $\mathbf{0}$ & $\mathbf{0}$ & 3 & $\mathbf{0}$ & $\mathbf{0}$ & 0 & 1 & 12 & $\mathbf{0}$ & $\mathbf{0}$ & 17 \\
\hline 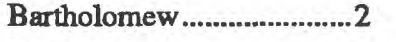 & 0 & $\mathbf{0}$ & 1 & $\mathbf{0}$ & 1 & 0 & 0 & 1 & 0 & 1 & 0 & 6 \\
\hline Benton ................................... & 0 & $\mathbf{0}$ & 0 & 0 & 0 & 0 & 0 & $\mathbf{0}$ & 2 & $\mathbf{0}$ & $\mathbf{0}$ & 2 \\
\hline 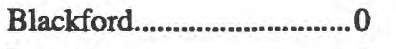 & 0 & 0 & 0 & 0 & 0 & 0 & 0 & 0 & 0 & 0 & 0 & 0 \\
\hline Boone & $\mathbf{0}$ & 0 & $\mathbf{0}$ & $\mathbf{0}$ & 0 & 0 & 0 & 1 & $\mathbf{0}$ & $\mathbf{0}$ & $\mathbf{0}$ & 1 \\
\hline 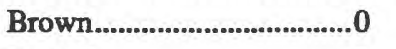 & 0 & 0 & 0 & $\mathbf{0}$ & 0 & 0 & 0 & 0 & 0 & 0 & 0 & 0 \\
\hline 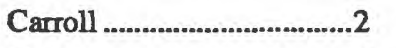 & 0 & 0 & 0 & $\mathbf{0}$ & 0 & 0 & 0 & 0 & 0 & 0 & 0 & 2 \\
\hline 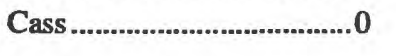 & 0 & 0 & $\mathbf{0}$ & 0 & 0 & 0 & 0 & 0 & 0 & 0 & 0 & 0 \\
\hline Clark & 1 & 0 & 0 & 0 & 0 & 0 & 0 & 0 & 0 & 0 & 0 & 1 \\
\hline 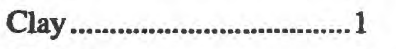 & 0 & 1 & 0 & $\mathbf{0}$ & 0 & 0 & 0 & $\mathbf{0}$ & 5 & $\mathbf{0}$ & 0 & 7 \\
\hline Clinton................................ & $\mathbf{0}$ & 0 & 0 & 0 & 0 & 0 & 0 & 0 & 0 & $\mathbf{0}$ & 0 & 0 \\
\hline Crawford & 0 & 0 & 0 & $\mathbf{0}$ & 0 & 0 & 0 & 0 & 0 & 0 & 0 & 0 \\
\hline 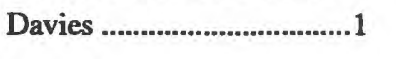 & $\mathbf{0}$ & 0 & 0 & 0 & 0 & 0 & 0 & 0 & $\mathbf{0}$ & $\mathbf{0}$ & 0 & 1 \\
\hline Dearborn ................................. & 0 & 0 & 0 & 0 & 0 & 0 & 0 & 0 & 0 & 0 & 0 & 3 \\
\hline Decatur & 0 & 0 & 0 & 1 & 0 & 1 & 1 & 0 & 0 & 1 & 0 & 4 \\
\hline DeKalb.................................. & 0 & 0 & 0 & 0 & 0 & 0 & 0 & 0 & 8 & 0 & 0 & 9 \\
\hline Delaware & 0 & 0 & 0 & 0 & 0 & $\mathbf{0}$ & 0 & 0 & 1 & 0 & 0 & 1 \\
\hline Dubois ...................................... 1 & 0 & 0 & 0 & 0 & 0 & 0 & 0 & 0 & 0 & 0 & 0 & 1 \\
\hline 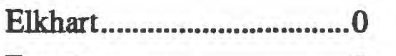 & 0 & 0 & 1 & 0 & 0 & 0 & 0 & 0 & 0 & 1 & 0 & 2 \\
\hline 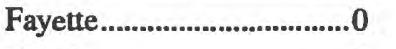 & 0 & 1 & 2 & $\mathbf{0}$ & 0 & 0 & 0 & 0 & 0 & $\mathbf{0}$ & 0 & 3 \\
\hline 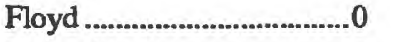 & 0 & $\mathbf{0}$ & 0 & 0 & $\mathbf{0}$ & 0 & 0 & 0 & 0 & $\mathbf{0}$ & 0 & 0 \\
\hline Fountain & 0 & 0 & 0 & 0 & 0 & $\mathbf{0}$ & 0 & 0 & 0 & 0 & 0 & 2 \\
\hline Franklin .................................... & $\mathbf{0}$ & $\mathbf{0}$ & $\mathbf{0}$ & $\mathbf{0}$ & 0 & 0 & $\mathbf{0}$ & $\mathbf{0}$ & $\mathbf{0}$ & 1 & 0 & 1 \\
\hline
\end{tabular}


Table 2. Indiana counties, with number and type of sample sites-Continued

\begin{tabular}{|c|c|c|c|c|c|c|c|c|c|c|c|c|}
\hline \multirow[b]{3}{*}{ County } & \multicolumn{8}{|c|}{ Public-Water Supply } & \multirow[b]{3}{*}{ DOM } & \multirow[b]{3}{*}{ OBS } & \multirow[b]{3}{*}{ SPR } & \multirow[b]{3}{*}{ TOT } \\
\hline & \multicolumn{2}{|c|}{$\begin{array}{l}\text { Community- } \\
\text { water system }\end{array}$} & \multicolumn{6}{|c|}{$\begin{array}{l}\text { Non-communlity- } \\
\text { water system }\end{array}$} & & & & \\
\hline & SDV & MHP & SCH & CHR & GOL & CMP & GOV & $\overline{\text { OTH }}$ & & & & \\
\hline Fulton ...................................... 0 & $\mathbf{0}$ & 0 & 0 & 0 & 0 & 0 & 0 & $\mathbf{0}$ & 0 & 0 & 0 & 0 \\
\hline Gibson..................................... & $\mathbf{0}$ & 0 & 0 & 0 & 0 & 0 & 0 & $\mathbf{0}$ & 0 & 0 & 0 & 1 \\
\hline Grant ......................................... 4 & 0 & 0 & 2 & 0 & 1 & 0 & 0 & 0 & 0 & 1 & 0 & 8 \\
\hline 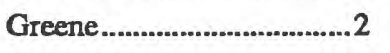 & 0 & $\mathbf{0}$ & 0 & 0 & 0 & 0 & 0 & 0 & 0 & 0 & 0 & 2 \\
\hline Hamilton & 0 & 0 & 0 & 0 & 0 & 0 & 0 & 0 & 1 & 2 & 0 & 4 \\
\hline 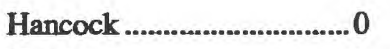 & 0 & 0 & 2 & 0 & 1 & 0 & 0 & 0 & 14 & 0 & 0 & 17 \\
\hline Harrison ............................... 0 & 0 & 0 & 0 & 0 & 0 & 0 & 0 & $\mathbf{0}$ & 0 & 1 & 0 & 1 \\
\hline Hendricks ............................... & 0 & 0 & 0 & 0 & 0 & 0 & 0 & 0 & 12 & 0 & 0 & 12 \\
\hline Henry .................................... & 0 & 0 & 0 & 0 & 0 & 0 & 0 & 0 & 1 & 0 & 0 & 2 \\
\hline Howard.................................. 1 & 0 & 0 & 0 & 0 & 0 & 0 & 0 & 0 & 0 & 0 & 0 & 1 \\
\hline Huntington ............................. & 1 & 0 & 0 & 1 & 0 & 0 & 0 & 0 & 0 & 0 & 0 & 2 \\
\hline 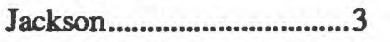 & 0 & 0 & 0 & 1 & 0 & 0 & 0 & $\mathbf{0}$ & $\mathbf{0}$ & 0 & 0 & 4 \\
\hline Jasper .................................... 1 & 0 & 0 & 0 & 1 & 0 & 0 & 0 & 1 & 8 & 3 & 0 & 14 \\
\hline Jay .................................................. & 0 & 0 & 0 & $\mathbf{0}$ & 0 & 0 & 0 & 0 & 0 & 0 & 0 & 0 \\
\hline Jefferson ............................... 0 & 0 & 0 & 0 & 0 & 0 & 0 & 1 & $\mathbf{0}$ & 0 & 0 & 0 & 1 \\
\hline 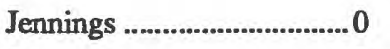 & 0 & 0 & 0 & 0 & 0 & 0 & 0 & 0 & 0 & 0 & 0 & 0 \\
\hline 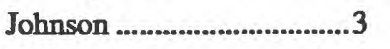 & 0 & 0 & 1 & 0 & 0 & 0 & 0 & 0 & 3 & 1 & 0 & 8 \\
\hline 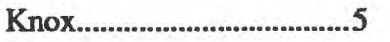 & 0 & 0 & 0 & 1 & 0 & 0 & 0 & 0 & 12 & 2 & 0 & 20 \\
\hline Kosciusko............................... & 0 & 0 & 0 & 0 & 0 & 0 & 0 & 0 & 39 & 2 & 0 & 43 \\
\hline LaGrange .............................. 2 & 0 & 0 & 7 & 0 & 0 & 1 & 0 & 0 & 8 & 2 & 0 & 20 \\
\hline 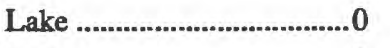 & 0 & 0 & 0 & 0 & 0 & 0 & 0 & 0 & 11 & 0 & 0 & 11 \\
\hline LaPorte.................................. 2 & 0 & 0 & 0 & 0 & 0 & 0 & 0 & 0 & 3 & 1 & 0 & 6 \\
\hline Lawrence............................. 1 & 0 & 0 & 0 & 0 & 0 & 0 & 0 & 0 & 0 & 0 & 0 & 1 \\
\hline Madison .............................. 5 & 0 & 1 & 0 & 1 & 0 & 0 & 0 & 0 & 3 & 0 & 0 & 10 \\
\hline Marion......................................... 0 & 0 & 0 & 0 & 1 & 3 & 1 & 0 & 0 & 0 & 2 & 0 & 7 \\
\hline Marshall ................................ 1 & 0 & 0 & 0 & 0 & 0 & 0 & 0 & $\mathbf{0}$ & 11 & $\mathbf{0}$ & 0 & 12 \\
\hline Martin...................................... & 0 & 0 & $\mathbf{0}$ & 0 & 0 & 0 & 0 & 0 & 0 & $\mathbf{0}$ & 0 & 3 \\
\hline 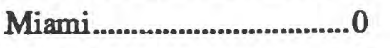 & 0 & 0 & 0 & 1 & 0 & 0 & 0 & 0 & 0 & 0 & 0 & 1 \\
\hline 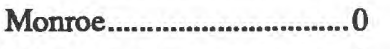 & 0 & 0 & 0 & 0 & 0 & 0 & 0 & 0 & 2 & 0 & 0 & 2 \\
\hline Montgomery.......................... 0 & 0 & 0 & 0 & 0 & 0 & 0 & 0 & 0 & 5 & 0 & 0 & 5 \\
\hline Morgan..................................... 1 & 0 & 0 & 0 & 0 & 0 & 0 & 0 & 0 & 5 & 2 & 0 & 8 \\
\hline Newton.................................. & 0 & 0 & 2 & $\mathbf{0}$ & 0 & 0 & 0 & 1 & 27 & 5 & 0 & 36 \\
\hline 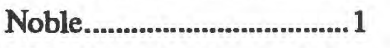 & 0 & 0 & 2 & 0 & 0 & 0 & 0 & 1 & 16 & 0 & 0 & 20 \\
\hline Ohio & 0 & 0 & 0 & 0 & 0 & 0 & 0 & 0 & 0 & 0 & 0 & 0 \\
\hline Orange........................................ & 0 & 0 & 1 & 4 & 0 & 0 & 0 & 0 & 9 & 0 & 2 & 18 \\
\hline
\end{tabular}


Table 2. Indiana counties, with number and type of sample sites-Continued

\begin{tabular}{|c|c|c|c|c|c|c|c|c|c|c|c|c|}
\hline \multirow[b]{3}{*}{ County } & \multicolumn{8}{|c|}{ Public-Water Supply } & \multirow[b]{3}{*}{ DOM } & \multirow[b]{3}{*}{ OBS } & \multirow[b]{3}{*}{ SPR } & \multirow[b]{3}{*}{ TOT } \\
\hline & \multicolumn{2}{|c|}{$\begin{array}{l}\text { Community- } \\
\text { water system }\end{array}$} & \multicolumn{6}{|c|}{$\begin{array}{l}\text { Non-community- } \\
\text { water system }\end{array}$} & & & & \\
\hline & SDV & MHP & $\overline{\mathrm{SCH}}$ & CHR & GOL & CMP & GOV & $\overline{\mathrm{OTH}}$ & & & & \\
\hline 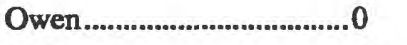 & 0 & 0 & 0 & 0 & 0 & 1 & 0 & 0 & 4 & 0 & 0 & 5 \\
\hline 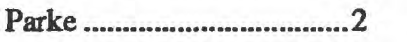 & 0 & 0 & $\mathbf{0}$ & 0 & 0 & 2 & 0 & 0 & 1 & 0 & 0 & 5 \\
\hline Perry & 0 & 0 & 0 & 0 & 0 & 0 & 0 & 0 & 0 & 0 & 0 & 1 \\
\hline Pike & 0 & 0 & 0 & 0 & 0 & 0 & 0 & 0 & 0 & 0 & 0 & 2 \\
\hline 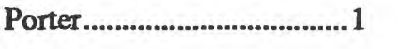 & 0 & 0 & 1 & 0 & 0 & 0 & 0 & 0 & 1 & 0 & 0 & 3 \\
\hline Posey & 0 & 0 & 1 & 0 & 0 & 0 & 0 & 0 & 0 & 1 & 0 & 3 \\
\hline Pulaski.................................1 & 0 & 0 & 0 & 0 & 0 & 0 & 0 & 0 & 0 & 0 & 0 & 1 \\
\hline Putnam & 0 & 0 & 0 & 0 & 0 & 0 & 0 & 0 & 2 & 0 & 0 & 2 \\
\hline Randolph............................ 3 & 0 & 0 & 0 & 0 & 0 & 0 & 0 & 0 & 2 & 0 & 0 & 5 \\
\hline Ripley ........................................ & 0 & 0 & 0 & 1 & 0 & 0 & 0 & 0 & 0 & 0 & 0 & 3 \\
\hline Rush & 0 & 0 & 0 & 0 & 0 & 0 & 0 & 0 & 1 & 0 & 0 & 5 \\
\hline St. Joseph .......................... 0 & 0 & 0 & 0 & 2 & 0 & 0 & 0 & 0 & 1 & 1 & 0 & 4 \\
\hline Scott $\ldots \ldots \ldots \ldots \ldots \ldots$ & 0 & 0 & 0 & 0 & 0 & 0 & 0 & 0 & 0 & 0 & 0 & 0 \\
\hline 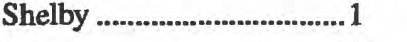 & 0 & 0 & 1 & 0 & 0 & 0 & 0 & $\mathbf{0}$ & 0 & 0 & 0 & 2 \\
\hline Spencer.................................. & 0 & 0 & 0 & 0 & 0 & 0 & 0 & 0 & 0 & 0 & 0 & 2 \\
\hline Starke & 0 & 0 & 0 & 0 & 0 & 0 & 0 & 0 & 2 & 0 & 0 & 2 \\
\hline 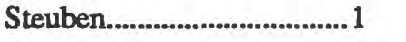 & 0 & 0 & 0 & 0 & 0 & 0 & 0 & 0 & 17 & 1 & 0 & 19 \\
\hline Sullivan & 0 & 0 & 1 & 1 & 0 & 0 & 0 & 0 & 16 & 0 & 0 & 22 \\
\hline Switzerland ........................... 1 & 0 & 0 & 0 & 0 & 0 & 0 & 0 & 0 & 0 & 0 & 0 & 1 \\
\hline Tippecanoe............................. 1 & 0 & 0 & 0 & 0 & 1 & 0 & 0 & 0 & 30 & 1 & 0 & 33 \\
\hline Tipton & 0 & 0 & 0 & 0 & 0 & 0 & 0 & 0 & 0 & 0 & 0 & 1 \\
\hline Union & 0 & 0 & 0 & 0 & 1 & 0 & 0 & 0 & 0 & 0 & 0 & 1 \\
\hline Vanderburgh .............................. & 0 & 0 & 0 & 0 & 0 & 0 & 1 & 0 & 0 & 1 & 0 & 2 \\
\hline Vermillion.............................. & 0 & 0 & 0 & 0 & 0 & 0 & 0 & 0 & 0 & 0 & 0 & 2 \\
\hline Vigo ............................. & 0 & 0 & 0 & 0 & 0 & 0 & 0 & 0 & 0 & 0 & 0 & 3 \\
\hline Wabash.................................... 2 & 0 & 0 & 0 & 0 & 0 & 0 & 0 & 0 & 0 & 1 & 0 & 3 \\
\hline Warren & 0 & 0 & 0 & 0 & 0 & 0 & 0 & 0 & 0 & 0 & 0 & 1 \\
\hline Warrick …............................ & 0 & 0 & 0 & 0 & 0 & 0 & 0 & 0 & 0 & 1 & 0 & 3 \\
\hline Washington ............................ 0 & 0 & 0 & 0 & 0 & 0 & 0 & 0 & 1 & 0 & 0 & 0 & 1 \\
\hline Wayne ................................... 1 & 0 & 0 & 0 & 0 & 0 & 0 & 0 & 0 & 0 & 1 & 0 & 2 \\
\hline Wells .................................. 1 & 0 & 0 & 0 & 0 & 0 & 0 & 0 & 0 & 0 & 0 & 0 & 1 \\
\hline White......................... & 0 & 0 & 0 & 0 & 0 & 0 & 0 & 2 & 0 & 0 & 0 & 3 \\
\hline Whitley.................................... 1 & 0 & 0 & 1 & 0 & 0 & 1 & 0 & 0 & 0 & 0 & 0 & 3 \\
\hline TOTALS ........................... 101 & 2 & 3 & 26 & 20 & 8 & 7 & 3 & 9 & 304 & 36 & 2 & 521 \\
\hline
\end{tabular}


EXPLANATION

NUMBER OF WELLS SAMPLED

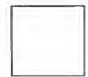

0

$1-5$

$6-10$

$11-19$

$20-43$
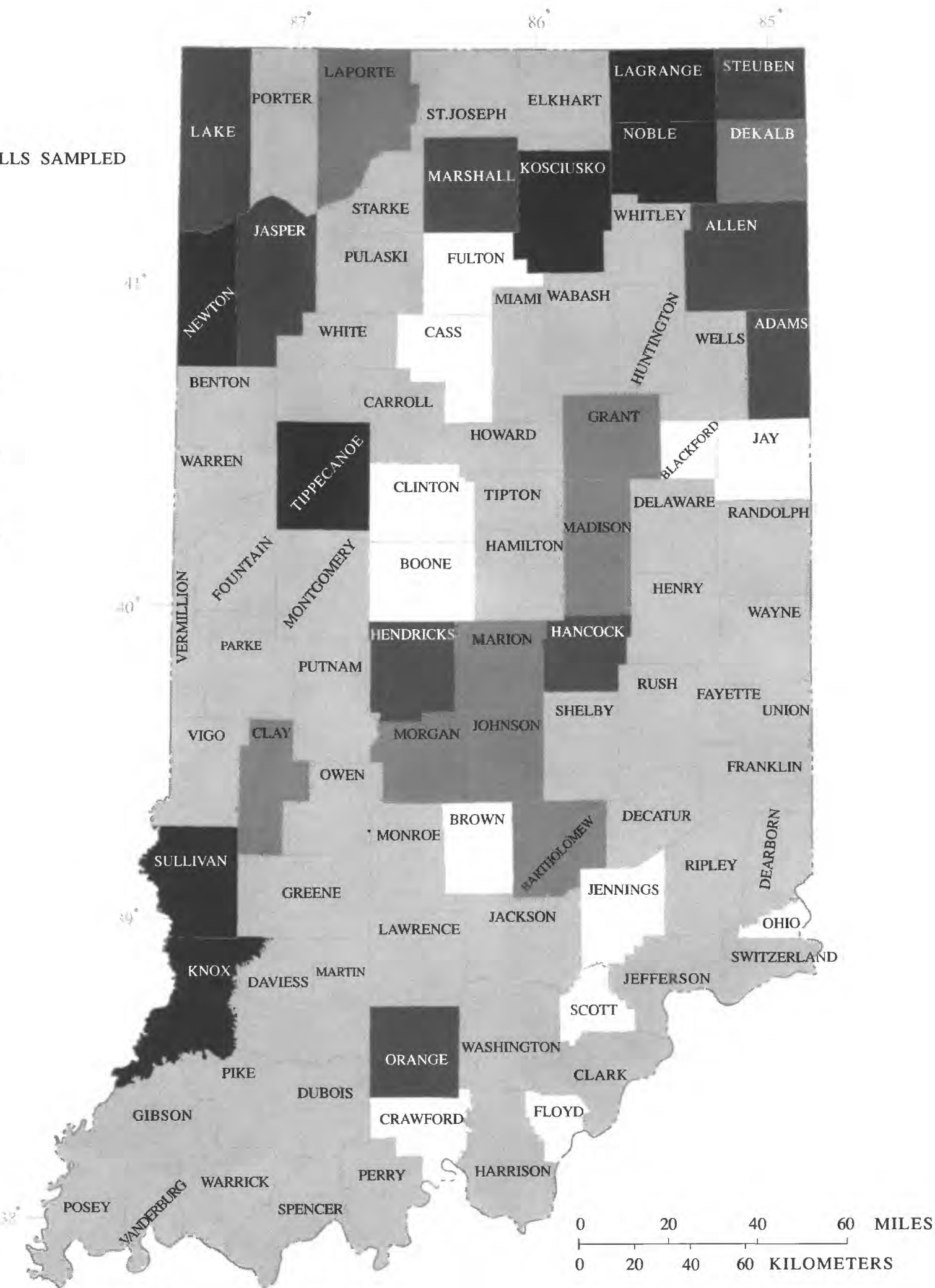

Base from U.S. Geological Survey digital

data 1:2,000,000 Albers Projection

Figure 6. Distribution of sites sampled for pesticides during 1985-91. 16 A Sumary of Pesticides in Ground-Water Data 
The well driller's log, geologist's field notes, and water-system operator interviews were primary sources of information. Well depths were available for 449 of the 519 wells in the data base ( 86 percent). These well depths ranged from 10 to 470 feet. Ninety percent of the sites in the data base had adequate documentation for a geologic unit to be assigned for the total depth of the well. Geologic units ranged from general categories (such as Quaternary Period or Paleozoic Era) to more specific categories (such as Pleistocene outwash or Blue River Group or Borden Formation). The degree of specificity was dependent on the data available for each well. About 79 percent of the sites with geologic information were wells completed in unconsolidated Pleistocene deposits. Wells completed in Paleozoic bedrock comprised the remainder of the sites.

\section{Ground-Water Samples}

Forty-one percent of the sites were sampled on more than one occasion. Water samples were collected on different dates at 212 of the 521 wells and springs. Also, approximately 17 percent of all samples were quality-assurance replicates collected immediately after the first sample at a site. Results for 150 replicate samples were entered in the data base but were not included in the data summary of this report.

Although the data base covers the time period December 1985 through April 1991, 68 percent of the samples were collected in calendar years 1988 and 1989. These samples accounted for 70 percent of the pesticide detections. Seventy-three percent of all samples were collected in the spring and summer seasons, March 21 through September 22; 85 percent of the samples in which pesticides were detected had been collected in these seasons (table 3). The proportion of detections in a season to the number of samples collected in that season was 7.3 percent for spring, 6.4 percent for summer, 5.0 percent for fall, and 2.1 percent for winter.
Table 3. Number of samples and detections in the data base, by year and by season

[Spring is March 21-June 22, Summer is June 23-September 22, Fall is September 23-December 22, Winter is December 23-March 20]

\begin{tabular}{ccc}
\hline Year/season & Samples & Detections \\
\hline 1985 & 2 & 1 \\
1986 & 34 & 5 \\
1987 & 71 & 6 \\
1988 & 272 & 13 \\
1989 & 322 & 22 \\
1990 & 143 & 1 \\
1991 & 31 & 3 \\
Spring & 340 & 24 \\
Summer & 297 & 19 \\
Fall & 99 & 5 \\
Winter & 139 & 3 \\
\hline
\end{tabular}

\section{Analytes}

Table 4 lists 97 analytes in the data base that include 87 pesticides and 10 pesticide metabolites. Also shown for each analyte are the number of samples and the minimum reporting limits, plus the pesticide use and current regulatory status (from USEPA, 1990b, and Sine, 1991). This list includes 55 pesticides that still can be used in the State, including those with restricted use, those under special review, and those being evaluated for re-registration by USEPA. Among the 29 pesticides which currently cannot be used, USEPA has not registered 4, and has cancelled or accepted the voluntary cancellation of 25 . The data base includes four metabolites of cancelled pesticides. Pesticide uses for the analytes include 36 herbicides, 44 insecticides, 2 fungicides, 7 soil or grain fumigants, 5 nematocides, and 1 defoliant. Table 4 includes 5 analytes with multiple uses and 10 pesticide metabolites. The number of samples for which each analyte was tested varied from 30 samples for de-isopropylatrazine to 716 samples for alachlor. At least 500 samples were tested for 38 of the 97 analytes. 
Table 4. Pesticides and metabolites in the data base, with number of samples, pesticide use, regulatory status, and range of minimum reporting limits

All analytes reported as total recoverable concentration in micrograms per liter $(\mu \mathrm{g} / \mathrm{L})$ unless otherwise noted

Pesticide Use: H, herbicide; I, insecticide; N, nematocide; F, fumigant; FG, fungicide; DF, defoliant; $M$, metabolite

Regulatory Status ${ }^{1}$ :

$R, R e$-registration-USEPA is evaluating for re-registration existing pesticides originally registered prior to current regulatory or scientific standards

RUP, USEPA has restricted the use of this registered pesticide active ingredient to certified applicators

S, Special Review-USEPA is conducting an intensive and systematic review of the pesticide to verify if continued use could result in unreasonable adverse effects on human health or the environment

C, cancelled-USEPA has cancelled the pesticide registration or the registration has been voluntarily cancelled by the product registrant

N, Not Registered-USEPA has not registered the pesticide for use

M, Metabolite (degradation product)-pesticide active ingredient has degraded or changed in the environment into this chemical

T, Contaminant-Pesticide may contain this contaminant, which is neither a registered active ingredient nor a metabolite

\begin{tabular}{|c|c|c|c|}
\hline Pesticide or metabolite name & $\begin{array}{l}\text { Pesticide } \\
\text { use }\end{array}$ & $\begin{array}{c}\text { Regulatory } \\
\text { status }\end{array}$ & $\begin{array}{l}\text { Range of } \\
\text { minimum } \\
\text { reporting } \\
\text { limits }(\mu g / L)\end{array}$ \\
\hline 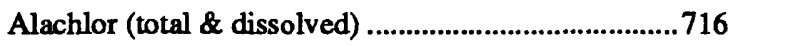 & $\mathbf{H}$ & R,RUP,S & $0.06-5.0$ \\
\hline Aldicarb & $\mathrm{I}, \mathrm{N}$ & R,RUP,S & 1.4 \\
\hline Aldicarb Sulfone & $\mathbf{M}$ & $\mathbf{M}$ & 1.2 \\
\hline Aldicarb Sulfoxide & $\mathbf{M}$ & $\mathbf{M}$ & 1.7 \\
\hline Aldrin & I & $\mathrm{C}$ & $.02-1.0$ \\
\hline Ametryne & $\mathbf{H}$ & $\mathbf{R}$ & $.05-0.5$ \\
\hline Atraton & $\mathbf{H}$ & $\mathbf{N}$ & .34 \\
\hline 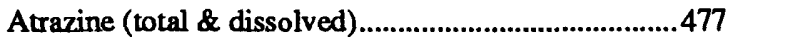 & $\mathbf{H}$ & R,RUP,S & $.1-4.4$ \\
\hline Azinphos-methyl & I & RUP & $2.0-4.6$ \\
\hline 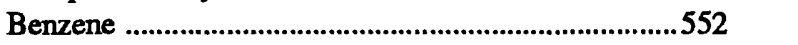 & I & C & $.2-1.0$ \\
\hline 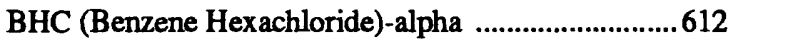 & I & $\mathbf{T}$ & $.01-0.12$ \\
\hline BHC-delta & I & $\mathbf{T}$ & $.02-1.0$ \\
\hline 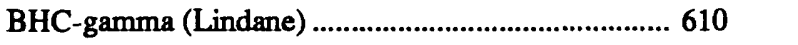 & I & C & $.01-1.0$ \\
\hline 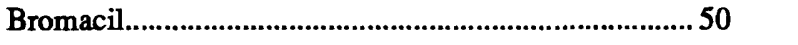 & $\mathbf{H}$ & $\mathbf{R}$ & 2.2 \\
\hline Bromomethane & $\mathbf{F}$ & R,RUP,S & $1.0-10$ \\
\hline Butachlor & $\mathbf{H}$ & $\mathbf{N}$ & 1.5 \\
\hline Butylate & $\mathbf{H}$ & $\mathbf{R}$ & $.6-37$ \\
\hline Carbaryl & I & $\mathbf{R}$ & 1.2 \\
\hline Carbofuran & I & R,RUP,S & $1.8-18$ \\
\hline 3-Hydroxy-carbofuran & $\mathbf{M}$ & $\mathbf{M}$ & 2.1 \\
\hline 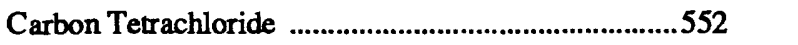 & $\mathbf{F}$ & $\mathrm{C}$ & $.2-5.0$ \\
\hline Chlordane & I & $\mathrm{C}$ & $.05-1.0$ \\
\hline 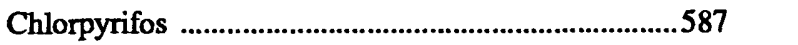 & I & $\mathbf{R}$ & $.05-30$ \\
\hline 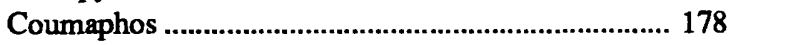 & I & $\mathbf{R}$ & $.05-10$ \\
\hline Cyanazine & $\mathbf{H}$ & R,RUP & $.09-8.0$ \\
\hline Dalapon & $\mathbf{H}$ & $\mathbf{R}$ & .6 \\
\hline DBCP(1,2-Dibromo-3-chloropropane)...................... 566 & $\mathbf{F}$ & C & $.02-1.0$ \\
\hline DCPA (Dacthal) & $\mathbf{H}$ & $\mathbf{R}$ & $.1-0.12$ \\
\hline 4,4' DDD (Dichlorodiphenyl-dichloroethane) ..........562 & I & C & $.05-1.0$ \\
\hline 4,4' DDE (Dichlorodiphenyl-dichloroethylene) ........562 & $\mathbf{M}$ & $\mathbf{M}$ & $.05-0.1$ \\
\hline 4,4' DDT (Dichlorodiphenyl-trichloroethane) ..........562 & I & C & $.05-0.1$ \\
\hline Demeton & I & C & .5 \\
\hline De-ethylatrazine (total \& dissolved) ................................ 81 & $\mathbf{M}$ & $\mathbf{M}$ & .05 \\
\hline De-isopropylatrazine (dissolved) ..................................... 30 & $\mathbf{M}$ & $\mathbf{M}$ & .05 \\
\hline Diazinon & $\mathbf{I}, \mathbf{N}$ & $\mathbf{R}$ & $.2-0.6$ \\
\hline Dicamba & $\mathbf{H}$ & $\mathbf{R}$ & $.04-9.0$ \\
\hline Dichloroprop & $\mathbf{H}$ & $\mathbf{R}$ & .5 \\
\hline Dichlorvos & I & $\mathbf{R}, \mathbf{S}$ & $.24-0.6$ \\
\hline
\end{tabular}


Table 4. Pesticides and metabolites in the data base, with number of samples, pesticide use, regulatory status, and range of minimum reporting limits-Continued

\begin{tabular}{|c|c|c|c|}
\hline Pesticide or metabolite name & $\begin{array}{c}\text { Pesticide } \\
\text { use }\end{array}$ & $\begin{array}{l}\text { Regulatory } \\
\text { status }\end{array}$ & $\begin{array}{c}\text { Range of } \\
\text { minimum } \\
\text { reporting } \\
\text { limits }(\mu g / L)\end{array}$ \\
\hline Dieldrin & I & $\mathbf{C}$ & $.05-1.0$ \\
\hline 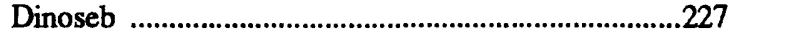 & $\mathrm{H}$ & C & $.5-2.5$ \\
\hline 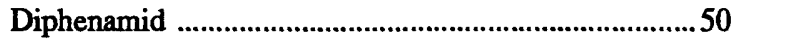 & $\mathrm{H}$ & C & .43 \\
\hline Disulfoton & I & R,RUP & $.2-1.2$ \\
\hline EDB (1,2-Dibromomethane) ............................................. & $\mathbf{I , F}$ & $\mathbf{C}$ & $.02-1.0$ \\
\hline 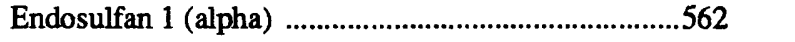 & I & $\mathbf{R}$ & $.04-0.05$ \\
\hline 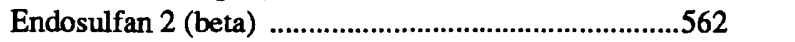 & I & $\mathbf{R}$ & $.05-1.0$ \\
\hline 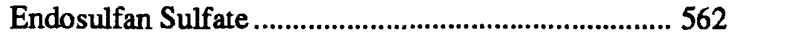 & $\mathbf{M}$ & $\mathbf{M}$ & $.05-1.0$ \\
\hline 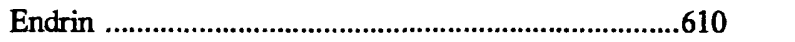 & I & C & $.05-1.0$ \\
\hline Endrin Aldehyde & $\mathbf{M}$ & $\mathbf{M}$ & $.05-1.0$ \\
\hline Endrin Ketone ............................................................ & $\mathbf{M}$ & $\mathbf{M}$ & .1 \\
\hline Ethoprop & $\mathrm{I}, \mathrm{N}$ & $\mathbf{R}, \mathbf{R U P}$ & $.12-0.3$ \\
\hline 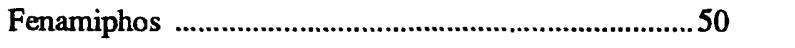 & I & $\mathbf{R}, \mathbf{R U P}$ & .3 \\
\hline Fonofos & I & $\mathbf{R}, \mathbf{R U P}$ & $.2-4.0$ \\
\hline Heptachlor & I & $\mathrm{C}$ & $.02-0.05$ \\
\hline Heptachlor Epoxide .....................................................613 & $\mathbf{M}$ & $\mathbf{M}$ & $.02-1.0$ \\
\hline 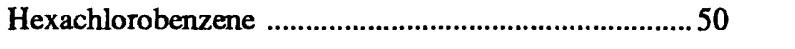 & FG & $\mathrm{C}, \mathrm{T}$ & .12 \\
\hline 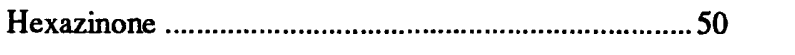 & $\mathbf{H}$ & $\mathbf{R}$ & .27 \\
\hline Malathion & I & $\mathbf{R}$ & $.08-\quad 1.0$ \\
\hline 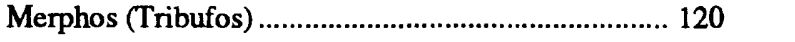 & DF & $\mathbf{P}$ & $.2-0.6$ \\
\hline 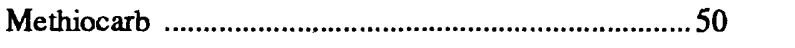 & I & $\mathbf{R}$ & 2.9 \\
\hline 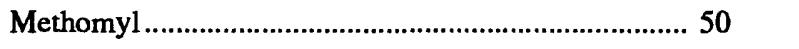 & I & R,RUP & 1.2 \\
\hline Methoxychlor & I & $\mathbf{R}$ & $.05-1.0$ \\
\hline 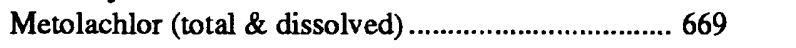 & $\mathbf{H}$ & $\mathbf{R}$ & $.1-10$ \\
\hline 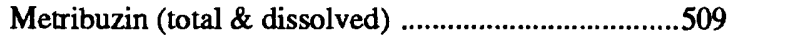 & $\mathbf{H}$ & $\mathbf{R}$ & $.05-180$ \\
\hline Mevinphos (Phosdrin) & I & R,RUP & $.3-1.0$ \\
\hline Napthalene & I & $\mathbf{R}$ & 1.0 \\
\hline 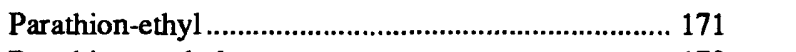 & $\mathbf{I}$ & R,RUP & $.2-0.3$ \\
\hline 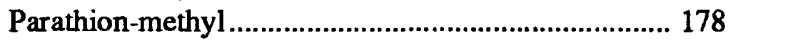 & I & $\mathbf{R}, \mathbf{R U P}$ & $.2-0.4$ \\
\hline PCP (Pentachlorophenol) & FG,I,H & R,RUP,S & .2 \\
\hline Pendimethalin & $\mathbf{H}$ & $\mathbf{R}$ & $.05-50$ \\
\hline Phorate & I & R,RUP & $.2-2.0$ \\
\hline Picloram & $\mathbf{H}$ & R,RUP & 1.0 \\
\hline Prometon & $\mathrm{H}$ & $\mathbf{R}$ & $.1-1.0$ \\
\hline Prometryne & $\mathbf{H}$ & $\mathbf{R}$ & $.1-2.0$ \\
\hline Propachlor & H & $\mathbf{R}$ & $.05-92$ \\
\hline Propazine (total \& dissolved) ......................................332 & $\mathbf{H}$ & $\mathrm{C}$ & $.05-2.0$ \\
\hline Propham & $\mathbf{H}$ & $\mathbf{C}$ & 11 \\
\hline 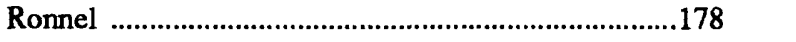 & I & C & $.2-1.0$ \\
\hline Simazine & $\mathrm{H}$ & $\mathbf{R}$ & $.1-14.4$ \\
\hline 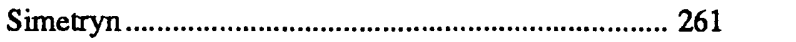 & $\mathrm{H}$ & $\mathbf{N}$ & $.1-0.5$ \\
\hline Stirofos (Tetrachlorvinphos) ............................................ 178 & I & $\mathbf{R}$ & $.5-10$ \\
\hline 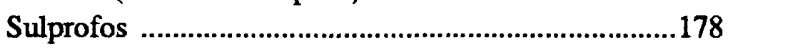 & I & R,RUP & $.2-\quad 0.4$ \\
\hline 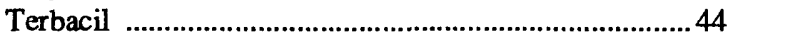 & $\mathrm{H}$ & $\mathbf{R}$ & 3.5 \\
\hline Terbufos & $\mathrm{I}, \mathrm{N}$ & $\mathbf{R}, \mathbf{R U P}$ & $.03-\quad 7.5$ \\
\hline Terbutryn (total \& dissolved) ............................................ 81 & $\mathrm{H}$ & $\mathrm{C}$ & $.05-\quad 0.3$ \\
\hline 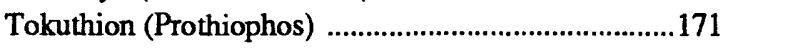 & I & $\mathbf{N}$ & $.2-0.4$ \\
\hline Toxaphene & I & $\mathbf{C}$ & $.1-4.0$ \\
\hline
\end{tabular}


Table 4. Pesticides and metabolites in the data base, with number of samples, pesticide use, regulatory status, and range of minimum reporting limits-Continued

\begin{tabular}{|c|c|c|c|}
\hline Pesticide or metabolite name & $\begin{array}{l}\text { Peaticido } \\
\text { use }\end{array}$ & $\begin{array}{l}\text { Regulatory } \\
\text { status }\end{array}$ & $\begin{array}{l}\text { Range of } \\
\text { minimum } \\
\text { reporting } \\
\text { limits }(\mu \mathrm{g} / \mathrm{L})\end{array}$ \\
\hline Trichloronate.................................................................. 178 & I & C & $.2-0.4$ \\
\hline Trifluralin ..........................................................................676 & H & $\mathbf{R}$ & $.03-2.0$ \\
\hline 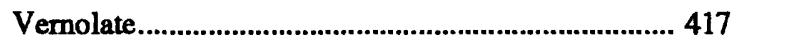 & $\mathbf{H}$ & $\mathbf{R}$ & $.37-7.0$ \\
\hline 1,2-Dichloroethane & $\mathbf{F}$ & $\mathbf{R}$ & $.2-1.0$ \\
\hline 1,2-Dichloropropane .......................................................... 602 & $\mathbf{F}$ & $\mathrm{C}, \mathrm{T}$ & $.2-5.0$ \\
\hline 1,2,4-Trichlorobenzene ................................................ 364 & H & $\mathbf{R}$ & 1.0 \\
\hline 1,3-Dichloropropene & $\mathbf{N}, \mathbf{F}$ & R,RUP & $.2-1.0$ \\
\hline 2,4-D (Dichlorophenoxyacetic Acid) ...........................627 & $\mathbf{H}$ & $\mathbf{R}$ & $.05-0.5$ \\
\hline 2,4-DB (Dichlorophenoxybutyric Acid) .......................227 & $\mathbf{H}$ & $\mathbf{R}$ & $1.0-2.0$ \\
\hline $2,4,5-\mathrm{T}$ (Trichlorophenoxyacetic Acid) $\ldots \ldots \ldots \ldots \ldots \ldots \ldots . . . . . . . . .227$ & $\mathbf{H}$ & C & $.1-0.2$ \\
\hline 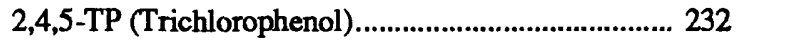 & $\mathbf{H}$ & C & $.04-0.2$ \\
\hline
\end{tabular}

\footnotetext{
${ }^{1}$ (from Sine, 1991, and USEPA, 1990b)
}

The minimum reporting limit is the smallest concentration of a chemical quantified in the sample analysis. Non-detections of analytes were presented as less than the minimum reporting limit concentration. For 72 of 97 analytes in the data base, there is a range of concentrations rather than a single concentration constituting the minimum reporting limit (table 4). This range exists because analyses were combined from multiple data sets. This range was 4 orders of magnitude for 1 analyte, metribuzin, $0.05-180$ micrograms per liter $(\mu \mathrm{g} / \mathrm{L})$. It was 3 orders of magnitude for 3 analytes (such as $0.05-30 \mu \mathrm{g} / \mathrm{L}$ for chlorpyrifos), and 2 orders of magnitude for 22 analytes. The lowest reporting limits were $0.01 \mu \mathrm{g} / \mathrm{L}$ for alpha-benzene hexachloride (BHC) and lindane, and $0.02 \mu \mathrm{g} / \mathrm{L}$ for aldrin, beta-BHC, heptachlor, heptachlor epoxide, EDB, and DBCP. The highest reporting limits, used for only six or fewer samples per analyte, were metribuzin $(180 \mu \mathrm{g} / \mathrm{L})$, propachlor $(92 \mu \mathrm{g} / \mathrm{L})$, and pendimethalin $(50 \mu \mathrm{g} / \mathrm{L})$.

\section{Pestlcide Detectlons}

At least 1 pesticide was detected at 41 of the 521 wells and springs ( 7.9 percent) from which water samples were obtained. These sites included
22 domestic wells, 8 community-water systems, 4 non-community systems, 5 USGS observation wells, and 2 springs. Twenty-six of the counties in the State had pesticides reported in ground water. Six counties had more than one site with pesticide detections-Noble (7), Newton (5), Orange (3), Kosciusko (2), Tippecanoe (2), and LaGrange (2). Table 5 lists by county the sites, samples, pesticides, metabolites, and concentrations. Figure 7 shows the locations of wells and springs listed in which pesticides were detected. Fifty-one of the 725 ground-water samples (7 percent) contained at least one detectable pesticide. Of the 16 samples with more than 1 pesticide present -3 samples had 6 pesticides, 3 samples had 5 pesticides, 1 sample had 3 pesticides, and 9 samples had 2 pesticides.

Well depths were known for 30 of 39 sites with pesticide detections and ranged from 12 to 260 feet; 73 percent were less than 100 feet (table 4). For the wells with pesticide detections for which there was geologic information, 78 percent were in unconsolidated deposits and 22 percent were in bedrock. 


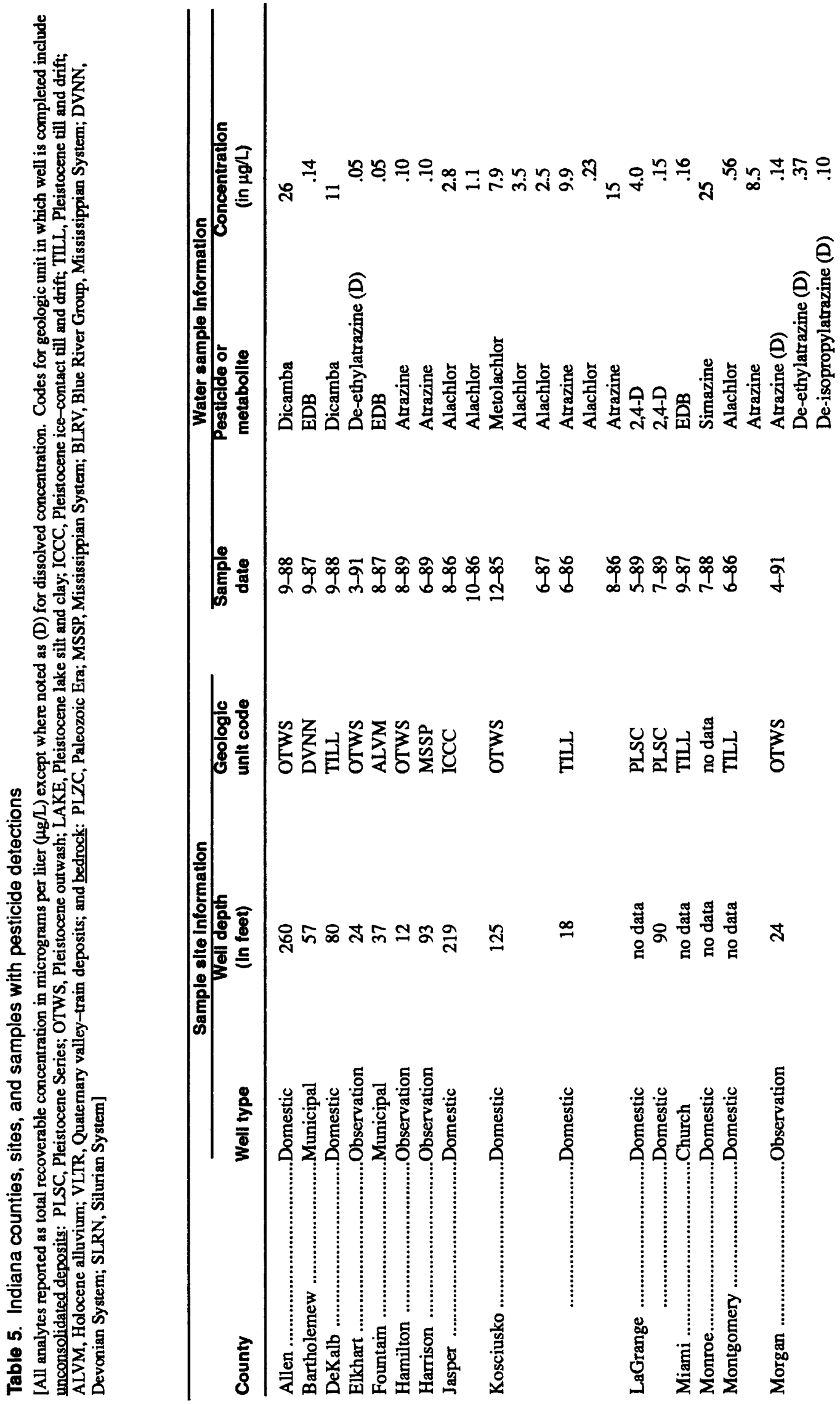




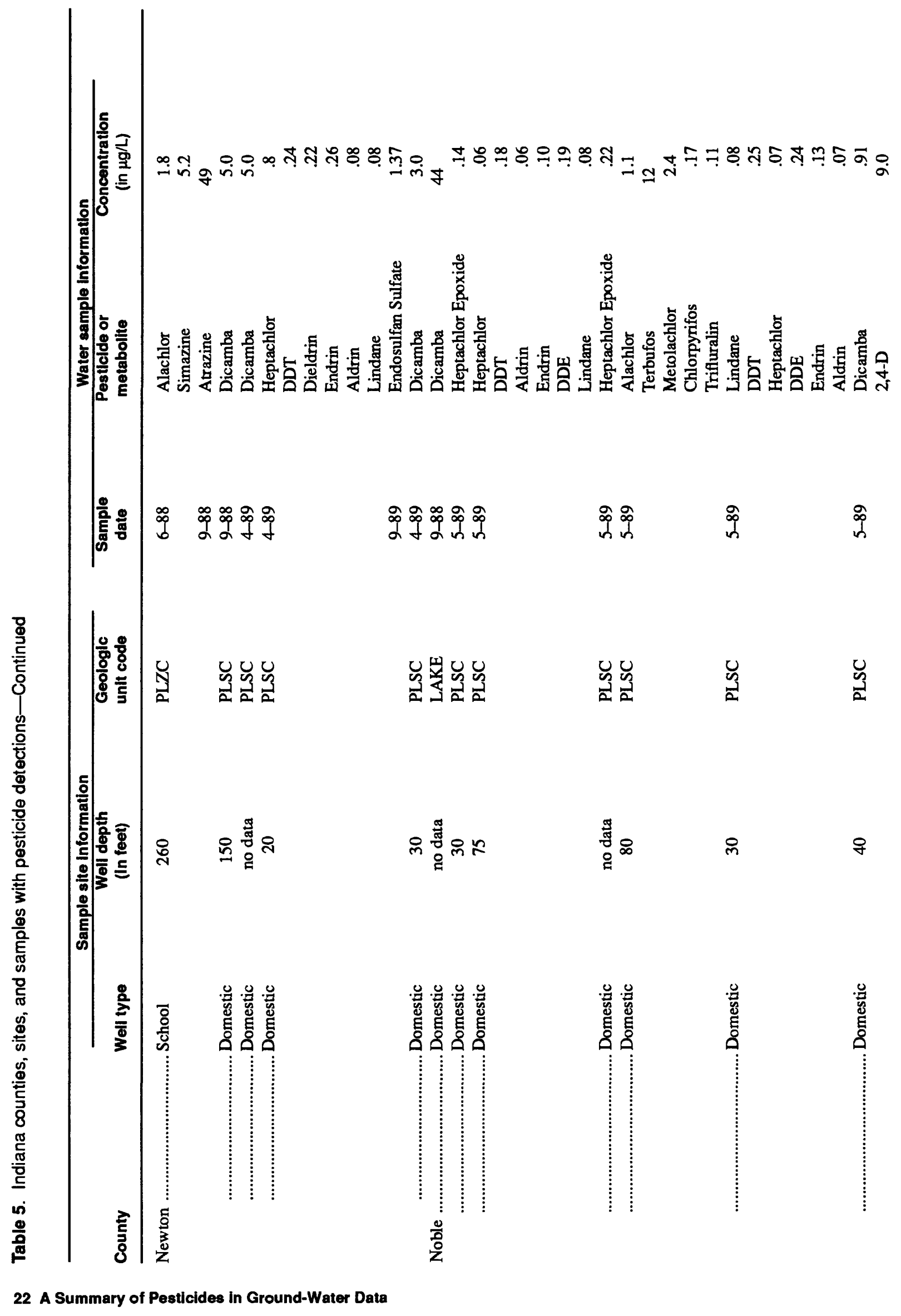




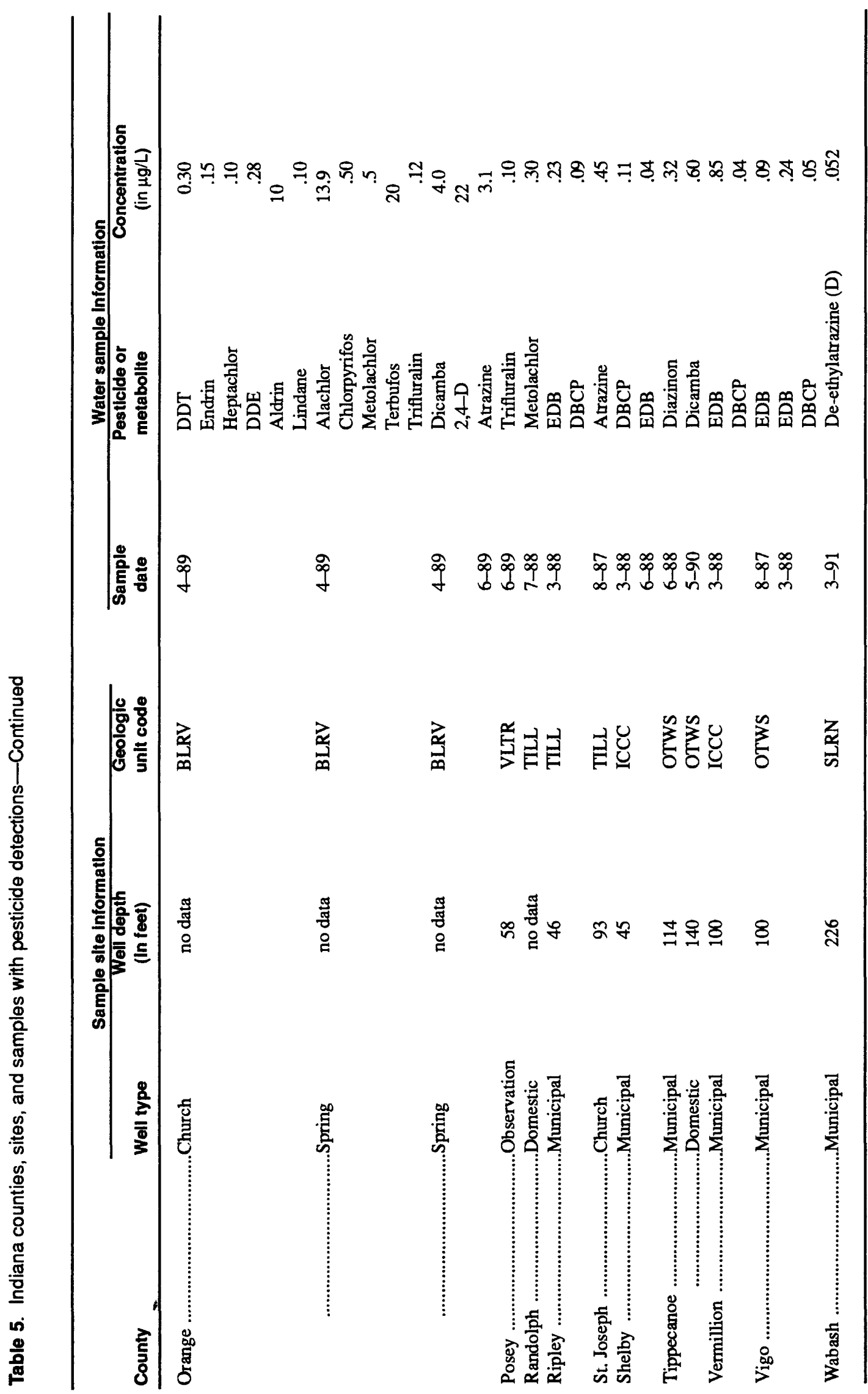




\section{EXPLANATION}

Sites with detection(s) of pesticides(s)/metabolite(s)

- Domestic-water-supply well

$\varnothing \quad$ USGS observation well

A Community-water-supply well

$\nabla$ Non-community water-supply well

Natural spring

Cluster of 5 or more domestic water-supply wells

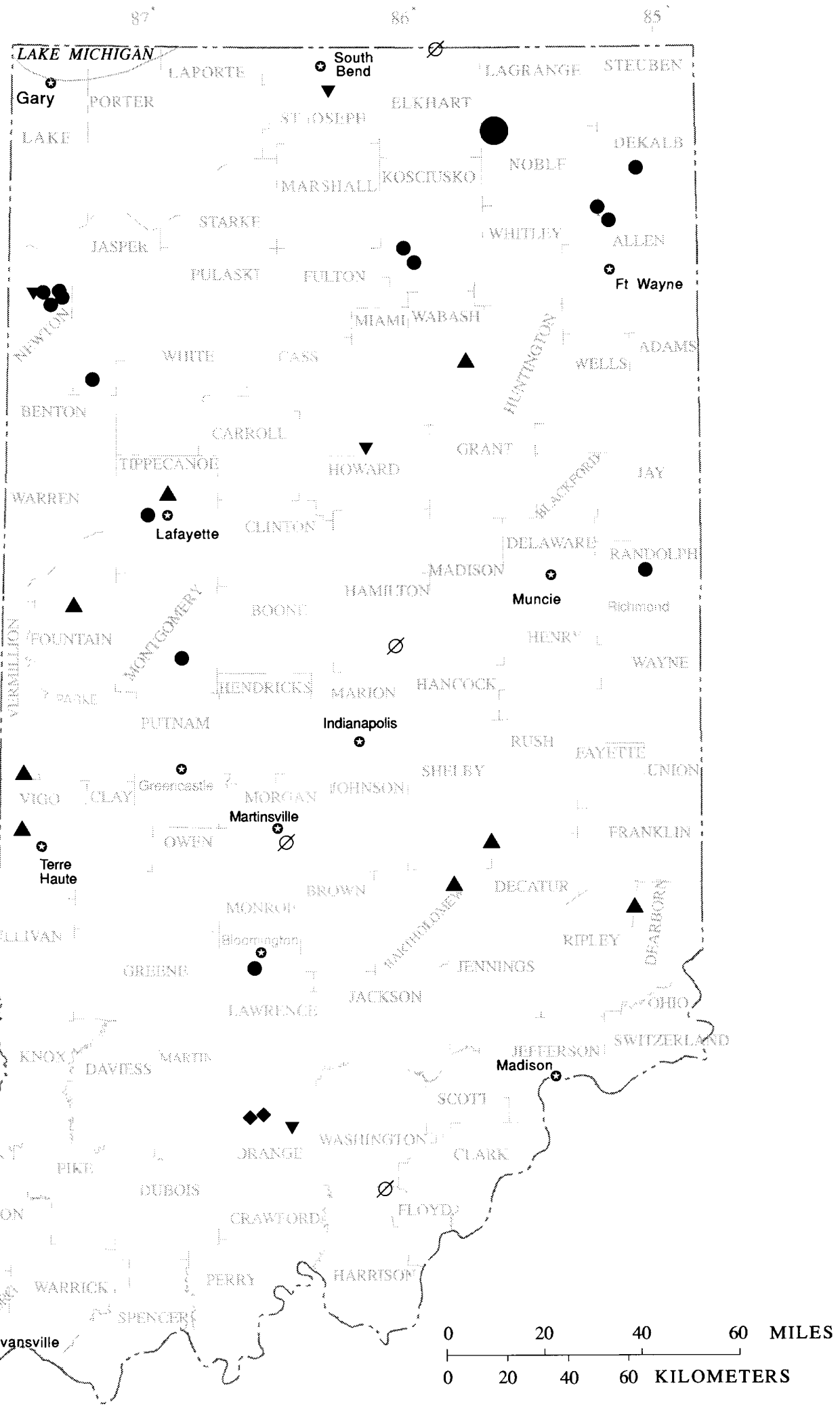

Base from U.S. Geological Survey digital data $1: 2,000,000$ Albers Projection

Figure 7. Location of sample sites with pesticide(s)/metabolite(s) detected during 1985-91. 
Eighteen pesticides and 5 pesticide metabolites were detected out of the 97 analytes in the data base. Table 6 lists the pesticides detected in Indiana ground water ranked by the number of samples that contained each pesticide. Table 6 also includes the range, mean, and median of the reported concentrations. Pesticide detections ranged in concentration from 0.04 to $49 \mu \mathrm{g} / \mathrm{L}$, and two-thirds of the detected concentrations were less than $1 \mu \mathrm{g} / \mathrm{L}$. Eleven pesticide detections were at a concentration between 10 and $49 \mu \mathrm{g} / \mathrm{L}$.

Pesticides with the highest number of individual detections were atrazine, alachlor, dicamba, and EDB. The largest number of samples were analyzed for alachlor (716) and metolachlor (669), but the frequency of detection was not highest for these pesticides. Two metabolites of atrazine, de-ethylatrazine and de-isopropylatrazine, had the highest frequency of detection (3.7 and 3.2 percent respectively). The number of samples analyzed for these chemicals (82 and 31), however, was substantially less than the number of samples analyzed for atrazine, alachlor, dicamba, and EDB.

Most of the pesticides and metabolites were detected at concentrations near the minimum reporting limit. The lowest reporting limit for each of the detected pesticides was between 0.01 and $0.2 \mu \mathrm{g} / \mathrm{L}$. The mean and median concentrations for 12 of the 23 detected pesticides and metabolites were within $0.2 \mu \mathrm{g} / \mathrm{L}$ of each analyte's lowest minimum reporting limit. Pesticides that had the highest mean and median concentrations, ranging from 1.3 to $16 \mu \mathrm{g} / \mathrm{L}$, were alachlor, atrazine, dicamba, metolachlor, simazine, terbufos, and 2,4-D.

Table 6. Pesticides and metabolites detected in Indiana ground water, ranked by number of detections, with number of samples, percent detections, and concentration range, mean, and median

[All analytes reported as total recoverable concentration in micrograms per liter $(\mu \mathrm{g} / \mathrm{L}$ ), unless otherwise noted as D (dissolved) or T\&D (total and dissolved) concentration]

\begin{tabular}{|c|c|c|c|c|c|c|}
\hline $\begin{array}{l}\text { Peaticide or } \\
\text { metabollte }\end{array}$ & $\begin{array}{l}\text { Number of } \\
\text { detections }\end{array}$ & $\begin{array}{c}\text { Number of } \\
\text { samples }\end{array}$ & $\begin{array}{l}\text { Detections as } \\
\text { percentage } \\
\text { of samples }\end{array}$ & $\begin{array}{c}\text { Range of } \\
\text { concen- } \\
\text { trations } \\
(\mu \mathrm{g} / \mathrm{L})\end{array}$ & $\begin{array}{l}\text { Mean } \\
\text { concen- } \\
\text { tration } \\
(\mu \mathrm{g} / \mathrm{L})\end{array}$ & $\begin{array}{c}\text { Modian } \\
\text { concen- } \\
\text { tration } \\
(\mu \mathrm{g} / L)\end{array}$ \\
\hline Atrazine (T\&I & $\ldots+. . .9$ & 477 & 1.9 & $0.10-49$ & 9.6 & 3.1 \\
\hline Alachlor .......... & ............... & 716 & 1.2 & $.23-13.9$ & 3.0 & 1.8 \\
\hline Dicamba ........ & $\ldots+. .9$ & 456 & 2.0 & $.6-44$ & 5 & 11 \\
\hline EDB & $\ldots+\ldots . . . . .8$ & 498 & 1.8 & $.04-0.85$ & 0.22 & 0.14 \\
\hline Metolachlor . & ................. & 669 & 0.6 & $.3-7.9$ & 2.8 & 1.4 \\
\hline DBCP & ................ & 566 & .7 & $.04-0.11$ & .07 & .06 \\
\hline 2,4-D $\ldots \ldots \ldots$ & ................. & 627 & .6 & $.15-22$ & 8.8 & 6.5 \\
\hline Lindane ............ & ................... & 610 & .6 & $.07-0.1$ & .08 & .08 \\
\hline DDT & ................. & 562 & .7 & $.18-0.3$ & .24 & .24 \\
\hline Aldrin & .............. & 612 & .6 & $.06-10$ & 2.5 & .08 \\
\hline Endrin ............... & .................. & 610 & .6 & $.10-0.26$ & .16 & .14 \\
\hline Heptachlor ... & ...................... & 612 & .6 & $.06-0.8$ & .26 & .08 \\
\hline De-ethylatrazi & ................... & 82 & 3.7 & $.05-0.37$ & .16 & .05 \\
\hline Trifluralin (Td & 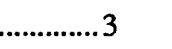 & 676 & .4 & $.10-0.12$ & .11 & .11 \\
\hline Endosulfan Su & $\ldots . . . . . .3$ & 562 & .5 & $.3-1.37$ & 1.3 & 1.3 \\
\hline DDE & ................... & 562 & .5 & $.19-0.28$ & .24 & .24 \\
\hline Simazine ........ & $\ldots . . . . . .2$ & 466 & .4 & $5.2-25$ & 15 & 15 \\
\hline Chlorpyrifos & ................... & 587 & .3 & $.17-0.50$ & .38 & .38 \\
\hline Terbufos ........ & .................. & 588 & .3 & $\begin{array}{ll}12 & -20\end{array}$ & 16 & 16 \\
\hline Heptachlor Ep & .................. & 613 & .3 & $.14-\quad .22$ & .18 & .18 \\
\hline De-isopropyla & $\ldots . . . . . . . .1$ & 31 & 3.2 & .1 & .1 & 0.1 \\
\hline Diazinon ......... & .................. & 180 & .5 & .32 & .32 & .32 \\
\hline Dieldrin ............ & $\ldots \ldots . . . . .1$ & 611 & .2 & .22 & .22 & .22 \\
\hline
\end{tabular}




\section{DISCUSSION OF PESTICIDE DETECTIONS}

Following is a discussion of the pesticide detections from four perspectives: (1) verification of detections by resampling, (2) quality-assurance replicates, (3) use of detected pesticides, and (4) concentrations compared with drinking-water standards. No interpretive analysis of the data is provided.

\section{Verlfication of Detectlons by Resampling}

At most sites, an attempt was made to verify the continued presence of the first-time pesticide detections by resampling within about 6 weeks. Resamples were analyzed for at least the pesticide(s) previously detected. At a few sites, the resample indicated some pesticide(s) not originally reported, and another resample was made.

Verification by resampling was attempted for 82 first-time detections, and no resamples occurred for 4 first-time detections. A total of 158 resamples was obtained for verification purposes, and only 5 of 82 (6 percent) first-time detections were confirmed (table 7). One repeat detection each of EDB, atrazine, and endosulfan sulfate was made. Two repeat detections of alachlor occurred, both near a site where storage and handling of pesticides was reported. Some of the resamples were taken in duplicate or triplicate, suggesting the non-detections were probably not false-negative results. No information was found to explain why so few of the pesticide detections could not be repeated.

\section{Quality-Assurance Replicates}

Twelve of the 51 samples with a pesticide detection were part of a set of quality-assurance replicates. Samples in a set of replicates were collected from a well in the same manner and within one-half-hour of each other. Comparisons of detections in a set of replicates may reflect the reproducibility of analytical results. Eight of the 12 sets of replicates contained 2 samples; 4 contained 3 samples. One replicate sample set had a pesticide detection in two of the three samples-EDB at .01 and $.04 \mu \mathrm{g} / \mathrm{L}$. No other set of replicates contained a pesticide detection in more than one of the two or three samples. No information was found to explain the lack of agreement among samples in sets of replicates with pesticide detections.

Table 7. Resamples for verification of pesticide detections

[Includes only those first-time detections for which verification resamples were collected]

\begin{tabular}{|c|c|c|}
\hline $\begin{array}{l}\text { Number of } \\
\text { first-time } \\
\text { detections }\end{array}$ & $\begin{array}{l}\text { Number of } \\
\text { resamples }\end{array}$ & $\begin{array}{l}\text { Number of } \\
\text { delectlons in } \\
\text { resamples }\end{array}$ \\
\hline Atrazine ......................... 8 & 12 & 1 \\
\hline Alachlor......................... 7 & 17 & 2 \\
\hline 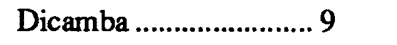 & 10 & 0 \\
\hline EDB & 18 & 1 \\
\hline Metolachlor ................. 4 & 5 & 0 \\
\hline DBCP & 11 & 0 \\
\hline 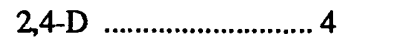 & 9 & 0 \\
\hline Lindane ........................ 4 & 9 & 0 \\
\hline DDT & 9 & 0 \\
\hline Aldrin & 9 & $\mathbf{0}$ \\
\hline Endrin ............................ 4 & 9 & 0 \\
\hline Heptachlor ................... 4 & 7 & 0 \\
\hline Trifluralin ...................... 3 & 5 & 0 \\
\hline Endosulfan Sulfate ...... 2 & 1 & 1 \\
\hline DDE 3 & 7 & 0 \\
\hline Simazine ....................... 2 & 5 & 0 \\
\hline Chlorpyrifos ................ 2 & 5 & 0 \\
\hline Terbufos ........................ 2 & 5 & 0 \\
\hline Heptachlor Epoxide ..... 2 & 2 & 0 \\
\hline Diazinon & 1 & 0 \\
\hline Dieldrin & 2 & 0 \\
\hline
\end{tabular}

\section{Use of Detected Pesticides}

Pesticides used in Indiana on com and soybeans during 1990 are ranked in table 8 by total pounds applied. Atrazine and alachlor, two herbicides with the highest number of detections in ground water, ranked the highest in pounds applied in 
1990. In contrast, dicamba, a herbicide detected as many times as atrazine and alachlor, ranked thirteenth in pounds applied. EDB was detected in ground water as many times as atrazine, alachlor, and dicamba, but the registration for EDB had been cancelled by USEPA in 1983. Metolachlor, like alachlor, is used on corn and soybeans and was third in total pounds applied in 1990. Metolachlor was noticeably lower, however, in number (4) and frequency ( 0.6 percent) of detections. Cyanazine and butylate, two of the five pesticides with over a million pounds applied in the State in 1990, were not detected in any samples.

Table 8. Corn and soybean pesticides used in Indiana in 1990 , by total pounds applied

\begin{tabular}{|c|c|c|c|}
\hline Rank & Pesticide & $\begin{array}{l}\text { Pounds applled } \\
\text { (In thouaands) }\end{array}$ & Crop \\
\hline $1 .$. & ...Alachlor & 7,320 & Corn, soybeans \\
\hline 2. & ....Atrazine & 6,334 & Corn \\
\hline 3. & ....Metolachlor & 3,619 & Corn, soybeans \\
\hline $4 .$. & ...Butylate & 2,436 & Corn \\
\hline 5. & ....Cyanazine & 1,905 & Corn \\
\hline 6. & ....Terbufos & 958 & Corn \\
\hline 7. & ....Trifluralin & 630 & Soybeans \\
\hline 8. & ...Bentazon & 473 & Soybeans \\
\hline $9 .$. & ...Metribuzin & 428 & Soybeans \\
\hline 10. & ...Fonofos & 370 & Corn \\
\hline $11 .$. & ...Chlorpyrifos & 370 & Corn \\
\hline $12 .$. & ...Linuron & 353 & Soybeans \\
\hline $13 .$. & ....Dicamba & 267 & Corn \\
\hline $14 .$. & $\ldots 2,4-\mathrm{D}$ & 263 & Corn \\
\hline $15 .$. & ...Pendimethalin & 244 & Soybeans \\
\hline $16 .$. & ...Acifluorfen & 84 & Soybeans \\
\hline $17 .$. & ...Imazaquin & 59 & Soybeans \\
\hline $18 .$. & ...Chlorimuron Ethyl & 40 & Soybeans \\
\hline $19 .$. & ...Tefluthrin & 27 & Corn \\
\hline $20 .$. & ...Imazethapyr & 20 & Soybeans \\
\hline
\end{tabular}

${ }^{1}$ (from USDA, 1991)

Prior to the detection of the 18 pesticides and 5 metabolites in Indiana ground water, USEPA had cancelled the registration for 8 of those pesticides and for parent compounds of 3 of those metabolites (table 4). The pesticides with cancelled registrations include the insecticides aldrin, dieldrin, DDT, $\mathrm{DBCP}, \mathrm{EDB}$, endrin, lindane, and heptachlor.

DDE, endosulfan sulfate, and heptachlor epoxide are the three metabolites of cancelled insecticides that were detected. According to Metcalf (1972), chlorinated insecticides such as aldrin, dieldrin, endrin, DDT, and heptachlor have degradation half-lives from 2 years to more than 4 years in soils. Chlorinated insecticides generally rank as the most persistent group of pesticides. Although the registrations for EDB and DBCP were cancelled in 1983 and 1979 respectively, these pesticides are persistent in the environment. Cohen and others (1984) referred to a study marking EDB's half-life in ground water at over 6 years at ambient conditions.

\section{Drinking-Water Standards and Pesticide Concentrations}

The concentrations of pesticides detected in Indiana ground water were compared to drinkingwater standards. The USEPA (1992) has promulgated a Maximum Contaminant Level (MCL) for certain chemicals, which is a maximum concentration limit for the treated water delivered to customers of public-water systems. The MCL is finalized during a rulemaking procedure that considers acceptable risks of adverse human health effects along with technological capabilities and economic costs of achieving those health protection goals. In general, MCL's are regarded as the standards for safe drinking water from public or private sources. For this discussion, if a final MCL for a detected pesticide exists, it was used for comparison against the pesticide concentration.

USEPA (1992) also issues a health advisory for certain chemicals in drinking water. Health advisories are unenforceable concentrations associated with risks of toxicity or cancer due to different lengths of exposure to a chemical. Although USEPA typically starts with a health advisory to determine a proposed $\mathrm{MCL}$, the health advisory is not adjusted by economic or technological factors as is the final MCL. Many chemicals for which there is no final MCL will have health advisories. For noncarcinogenic chemicals, a Health Advisory (HA) is set to protect human health for a lifetime of exposure. For carcinogens, a Health Advisory (HA-C) concentration is calculated for a probability of increased lifetime cancer risk. 
In this discussion, if there were no final MCL, the HA or HA-C was used for comparison against the pesticide concentration. For noncarcinogens, the adult lifetime exposure HA concentration was used. For carcinogens, the HA-C concentration corresponding to a cancer-risk probability of 1 in 100,000 was used instead of the HA. It was assumed that the $\mathrm{HA}$ and $\mathrm{HA}-\mathrm{C}$ were comparable to criteria used for an MCL. Therefore, the drinking-water standard used for comparison of concentrations of pesticides detected in Indiana ground water was either the MCL, HA, or HA-C.

Because 92 percent of the sample sites in the data base were drinking-water-supply wells, pesticide detections in all the water samples were compared to drinking-water standards. At the time of this report, MCL's were finalized for 8 of the 23 pesticides detected in Indiana, HA's were issued for 10 of the 23 pesticides, and HA-C's were issued for 2 of the 23 pesticides (table 9). Five of the 23 detected pesticides were without a standard-DDT, DDE, de-ethylatrazine, deisopropylatrazine, and endosulfan sulfate. The concentration for 26 of the 90 ( 29 percent) individual pesticide detections in the data base exceeded a MCL or a comparable HA or HA-C. Table 9 also shows that 9 of the 23 pesticides exceeded a standard at least once; those with the greatest number of detections above a MCL, HA, or HA-C were EDB (6), atrazine (5), alachlor (4), and aldrin (4).

\section{SUMMARY AND CONCLUSIONS}

Data collected from a limited number of locations in Indiana reveal that some ground water has been contaminated with pesticides. This finding is not unlikely because about 70 percent of Indiana's land use is agricultural and there are abundant rural ground-water supplies in the State. In 1990, more than 26 million pounds of com and soybean herbicides were applied to 13 million
Tabie 9. Pesticides and metabolites detected in Indiana ground water, with drinking-water standard, number and range of concentrations exceeding the standard

No drinking-water standard is available for the following pesticides and metabolites detected in Indiana ground water-DDE, DDT, endosulfan sulfate, de-ethylatrazine, and de-isopropylatrazine. All concentrations are in micrograms per liter $(\mu \mathrm{g} / \mathrm{L})$

Basis of Standard: MCL, Maximum Contaminant Level; HA, adult lifetime Health Advisory for chronic toxicity risk; HA-C, adult Health Advisory for excess lifetime cancer risk of 1 in 100,000 ; --, no data

\begin{tabular}{|c|c|c|c|}
\hline $\begin{array}{cc}\text { Pesticide } & \begin{array}{c}\text { Drinking } \\
\text { water }\end{array} \\
\text { or } & \text { standard } \\
\text { metabolite } & (\mu \mathrm{g} / \mathrm{L})\end{array}$ & $\begin{array}{l}\text { Basis of } \\
\text { standard } 1\end{array}$ & $\begin{array}{l}\text { Number of } \\
\text { detections } \\
\text { exceeding } \\
\text { standard }\end{array}$ & $\begin{array}{l}\text { Range of } \\
\text { concentrations } \\
\text { exceeding } \\
\text { standard } \\
(\mu \mathrm{g} / \mathrm{L})\end{array}$ \\
\hline Alachlor ................ 2 & MCL & 4 & $2.5-13.9$ \\
\hline Aldrin ..................... .02 & HA-C & 4 & $.6-10$ \\
\hline Atrazine ................ 3 & MCL & 5 & $3.1-49$ \\
\hline Chlorpyrifos .....20 & HA & 0 & -- \\
\hline DBCP & MCL & 0 & -- \\
\hline Diazinon .............. .6 & HA & 0 & -- \\
\hline Dicamba .......... 200 & HA & 0 & -- \\
\hline Dieldrin ............... .02 & HA-C & 1 & .22 \\
\hline EDB & MCL & 6 & $.09-.85$ \\
\hline Endrin .................... 2 & HA & 0 & -- \\
\hline Heptachlor .......... .4 & MCL & 1 & .8 \\
\hline $\begin{array}{l}\text { Heptachlor .......... . .2 } \\
\text { Epoxide }\end{array}$ & MCL & 1 & .22 \\
\hline Lindane ............... .2 & MCL & 0 & -- \\
\hline Metolachlor .... 100 & HA & 0 & -- \\
\hline Simazine ............. 4 & HA & 2 & $5.2-25$ \\
\hline Terbufos ............. .9 & HA & 2 & -20 \\
\hline Trifluralin ............. 5 & HA & 0 & -- \\
\hline 2,4-D ................ 70 & MCL & 0 & - \\
\hline
\end{tabular}

\footnotetext{
${ }^{1}$ (from USEPA, 1992)
}

acres of Indiana cropland. Nearly 60 percent of Indiana's population depends on ground water, including half of the State's public-water-system customers and the majority of rural residents.

The U.S. Geological Survey, in cooperation with the Indiana Department of Environmental Management, compiled the available pesticide analyses and ancillary data obtained from files at 
the Indiana Department of Environmental Management, the Indiana Department of Natural Resources, the U.S. Environmental Protection Agency, and the U.S. Geological Survey. The analytical results and sample-site information were entered into a computerized data base which contains analyses of 875 water samples from 521 sites in 81 of 92 counties throughout Indiana. The water samples had been collected by staff from these agencies using similar procedures, and were analyzed at government-operated and governmentcontractor laboratories. Most of the samples had been collected as part of 6 statewide surveys and 15 localized studies of pesticides in Indiana ground water. Forty-one percent of all sites were sampled more than once, and 150 of the 875 samples were quality-assurance replicates. Thirty wells in the data base were sampled in response to alleged ground-water contamination with pesticides.

In this report, the data were summarized for 725 pesticide samples collected from December 1985 through April 1991. Eight percent of the wells and springs contained at least one pesticide or metabolite, including 22 domestic wells, 8 community-system wells, 5 observation wells, 4 non-community-system wells, and 2 springs. Five of the wells with pesticide detections were associated with complaints of ground-water contamination from pesticide storage, handling, or application. About three-fourths of all the pesticide detections were in water from wells completed in unconsolidated materials to a depth less than 100 feet, but the depth of these wells ranged from 12 to 260 feet. Seventy-three percent of the samples collected and 85 percent of all detections were in the spring and summer seasons between March 21 and September 22; 68 percent of the samples collected and 70.percent of all detections were in calendar years 1988 and 1989.

Of the 87 pesticides and 10 metabolites in the data base, 23 were detected in ground water. The highest frequency of occurrence was observed for herbicides in widespread use-alachlor; atrazine and two atrazine metabolites (de-ethylatrazine and de-isopropylatrazine); dicamba; 2,4-D; and metolachlor. Thirty-six percent of all detections involved insecticides whose use was cancelled or restricted by USEPA prior to their detectionEDB, DBCP, aldrin, endrin, lindane, heptachlor, and DDT.

Concentrations of the detected pesticides ranged from 0.04 to 49 micrograms per liter. Most of the pesticides and metabolites were detected at concentrations near the minimum reporting limit, between 0.04 and 0.2 micrograms per liter. About 29 percent of the 90 individual pesticide detections were at concentrations above a drinking-water standard set to protect against long-term risks to human health. Eight pesticides and one metabolite were detected at concentrations in excess of a standard. Pesticides with the highest incidence above a standard were EDB, atrazine, alachlor, and aldrin.

Statewide inferences about the occurrence of pesticides in ground water cannot be based solely on this data compilation. The results were not due to a single statistical design but instead were derived from a combination of many data sets. Among the studies, there was bias or variation in the selection of sample sites, in the timing and frequency of sample collection, and in the selection and minimum reporting limits of analytes. Data was unavailable for some pesticides used in Indiana.

This summary of pesticide data in Indiana ground water can be beneficial in several ways. Used alone, this data compilation can help researchers select locations and pesticides in Indiana which merit more detailed scientific investigation. Findings from analysis of the data base could be used by regulatory agencies to identify pesticides and parts of the State that should be priorities for ground-water protection. In a geographic information system, the data on pesticide detections can be analyzed relative to spatial data such as soil characteristics, aquifer types, and land use-factors which may influence the occurrence of pesticides in ground water. Statistical inferences based on that analysis could be useful in the design of a statewide ground-water monitoring network for pesticides. 


\section{REFERENCES CITED}

Cohen, S.Z., Creeger, S.M., Carsel, R.F., and Enfield, C.G., 1984, Potential for pesticide contamination of ground water resulting from agricultural uses, in Krueger and Seiber, eds., Treatment and disposal of pesticide wastes, 1984, American Chemical Society symposium series 259: Washington, D.C., p. 307.

Indiana Department of Environmental Management, 1990, Indiana 305(b) report 1988-89: Indianapolis, Ind., IDEM, p.265-283.

Kolpin, D.W. and Burkhart, M.R., 1991, Work plan for regional reconnaissance for selected herbicides and nitrate in ground water of the mid-continental United States, 1991: U.S. Geological Survey Open-File Report 91-59, p. 3.

Metcalf, R.L., 1972, Agricultural chemicals in relation to environmental quality--insecticides today and tomorrow in Smith, J.A., Witkowski, P.J., and Fusillo, T.V., 1988, Man-made organic compounds in the surface waters of the United States--a review of current understanding: U.S. Geological Survey Circular 1007, p. 38.

Parsons, D.W. and Witt, J.M., 1988, Pesticides in the groundwater of the United States: Corvallis, Oregon State University Extension Service, p. 16.
Sine, C., ed. dr., 1991, Farm Chemicals Handbook '91: Willoughby, Ohio, Meister Publishing Company, $500 \mathrm{p}$.

U.S. Department of Agriculture, Indiana Agricultural Statistics Service, 1991, Indiana agriculture report special issue--agricultural chemical use survey, v.11, SP-5: West Lafayette, Ind., USDA, $8 \mathrm{p}$.

U.S. Environmental Protection Agency, Office of Water, April 1992, Drinking water regulations and health advisories: Washington, D.C., USEPA, $13 \mathrm{p}$.

U.S. Environmental Protection Agency, Office of Water, Office of Pesticides and Toxic Substances, 1990, Summary results of EPA's national survey of pesticides in drinking water wells: Washington, D.C., USEPA, 16 p.

1990, Survey analytes for EPA's national survey of pesticides in drinking water wells: Washington, D.C., USEPA, 16 p.

Williams, W.M., Holden, P.W., Parsons, D.W. and Lorber, M.N., 1988, Pesticides in ground water data base--1988 interim report: Washington, D.C., U.S. Environmental Protection Agency, p. 1-2. 